\title{
Article
}

\section{A Titanium (IV)-Dithiophenolate Complex and Its Chitosan Nanocomposite: Their Roles towards Rat Liver Injuries In Vivo and against Human Liver Cancer Cell Lines}

\author{
Nadia Z. Shaban 1,*, Salah A. Yehia ${ }^{1}$, Doaa Awad ${ }^{1}$, Shaban Y. Shaban ${ }^{2}$ (D) and Samar R. Saleh ${ }^{1}$ \\ 1 Biochemistry Department, Faculty of Science, Alexandria University, Alexandria 21515, Egypt; \\ salah.yehia_PG@alexu.edu.eg (S.A.Y.); doaaelsayed363@alexu.edu.eg (D.A.); \\ samar.saleh@alexu.edu.eg (S.R.S.) \\ 2 Chemistry Department, Faculty of Science, Kafrelsheikh University, Kafrelsheikh 33516, Egypt; \\ shaban.shaban@sci.kfs.edu.eg \\ * Correspondence: nadia.zaki@alexu.edu.eg; Tel.: +20-1227425785; Fax: +2-(03)-3911794
}

\section{check for}

updates

Citation: Shaban, N.Z.; Yehia, S.A.; Awad, D.; Shaban, S.Y.; Saleh, S.R. A Titanium (IV)-Dithiophenolate Complex and Its Chitosan

Nanocomposite: Their Roles towards Rat Liver Injuries In Vivo and against Human Liver Cancer Cell Lines. Int. J Mol. Sci. 2021, 22, 11219. https:// doi.org/10.3390/ijms222011219

Academic Editors: Valentina Villari and Magdalena Krystyjan

Received: 30 August 2021

Accepted: 11 October 2021

Published: 18 October 202

Publisher's Note: MDPI stays neutral with regard to jurisdictional claims in published maps and institutional affiliations.

Copyright: (c) 2021 by the authors. Licensee MDPI, Basel, Switzerland. This article is an open access article distributed under the terms and conditions of the Creative Commons Attribution (CC BY) license (https:/ / creativecommons.org/licenses/by/ $4.0 /)$.

\begin{abstract}
Titanium (IV)-dithiophenolate complex chitosan nanocomposites (DBT-CSNPs) are featured by their antibacterial activities, cytotoxicity, and capacity to bind with DNA helixes. In this study, their therapeutic effects against rat liver damage induced by carbon tetrachloride $\left(\mathrm{CCl}_{4}\right)$ and their anti-proliferative activity against human liver cancer (HepG2) cell lines were determined. Results of treatment were compared with cisplatin treatment. Markers of apoptosis, oxidative stress, liver functions, and liver histopathology were determined. The results showed that DBT-CSNPs and DBT treatments abolished liver damage induced by $\mathrm{CCl}_{4}$ and improved liver architecture and functions. DNA fragmentation, Bax, and caspase- 8 were reduced, but Bcl-2 and the Bcl-2/Bax ratios were increased. However, there was a non-significant change in the oxidative stress markers. DBT-CSNPs and DBT inhibited the proliferation of HepG2 cells by arresting cells in the G2/M phase and inducing cell death. DBT-CSNPs were more efficient than DBT. Low doses of DBT and DBT-CSNPs applied to healthy rats for 14 days had no adverse effect. DBT and DBT-CSNP treatment gave preferable results than the treatment with cisplatin. In conclusion, DBT-CSNPs and DBT have anti-apoptotic activities against liver injuries and have anti-neoplastic impacts. DBT-CSNPs are more efficient. Both compounds can be used in pharmacological fields.
\end{abstract}

Keywords: chitosan nanoparticles (CSNPs); titanium (IV)-dithiophenolate complex (DBT); DBTCSNPs; liver injury; apoptosis; oxidative stress; anti-proliferative; G2/M arrest

\section{Introduction}

The liver is the largest solid organ in the body and is required for survival. The liver has numerous functions including the synthesis of proteins, glucose, bile, and clotting factors and the breaking down of hormones, certain drugs, and xenobiotics [1,2]. Hepatic metabolism of some drugs and toxins such as carbon tetrachloride $\left(\mathrm{CCl}_{4}\right)$ augments the generation of free radicals and reactive oxygen species (ROS), resulting in oxidative stress (OS), hepatoxicity, and deterioration of macromolecules as proteins, lipids, carbohydrates, and nucleic acids $[3,4]$. The hepatotoxicity induced by xenobiotics is dependent on their dosage, nature, and period of exposure [1,2]. ROS and reactive nitrogen species (RNS) are well known for playing a dual function as both harmful and beneficial species. There is increasing evidence that "double-faced" ROS in cells act as secondary messengers in intracellular signaling cascades, which stimulate and preserve the oncogenic phenotype of cancer cells, while ROS can prompt cellular senescence and apoptosis and can thus function as antitumorigenic species $[5,6]$. $\mathrm{CCl}_{4}$ is an industrial chemical found in refrigerants and solvents for waxes, varnishes, and other materials. $\mathrm{CCl}_{4}$ is one of the most potent hepatotoxins $[5,6]$. In the liver, $\mathrm{CCl}_{4}$ is metabolized by cytochrome $\mathrm{P} 450$ into the trichloromethyl radical $\left({ }^{\bullet} \mathrm{CCl}_{3}\right)$, which is converted into trichloromethylperoxy radicals $\left(\mathrm{CCl}_{3} \mathrm{OO}{ }^{\bullet}\right)[5,6]$. 
Nanotechnology is a promising field of interdisciplinary research since it contributes to different fields, including pharmacology, parasitology, pest management, and electronics. In recent years, nanoparticles have received great attention owing to their various applications in many fields such as diagnostics, biomarkers, cell labeling [7], drug delivery, cancer therapy, and anti-flammable materials [8]. Chitosan (CS) is a natural polysaccharide and has unique characteristics frequently not detected in synthetic polymers [9]. CS nanoparticles (CSNPs) have the advantages of chitosan and the properties of nanoparticles such as surface and interface effect, small size, and quantum size effects. Therefore, the CSNPs have been reported to have key applications in ocular drug delivery, per-oral administration of drugs, brain-targeting drug delivery, parenteral drug delivery, non-viral gene delivery, vaccine delivery, mucosal drug delivery, tissue engineering, and the effective delivery of insulin $[10,11]$.

Liver diseases represent a major cause of serious and public health problems, leading to elevated levels of morbidity and mortality worldwide and in Egypt [12,13]. Chemotherapy still has a marked curative impact with substantial success in clinical practice. Although chemotherapy is an efficient way to treat many types of cancer, chemotherapy also causes serious side effects. Some chemotherapy side effects are moderate and treatable; however, others can cause dangerous complications [14]. Therefore, scientists are working to discover new treatments for liver diseases that are effective and have no/or minor side effects. Cisplatin is used to treat cancer; nonetheless, it causes serious side effects. In contrast, titanium $\mathrm{Ti}(\mathrm{IV})$ as a biomaterial is generally used in orthopedic implants such as the substitution of teeth and bone [15]. Titanium is characterized by its high effectiveness and low toxicity. In our previous studies, we prepared dithiophenolato ligand "DTP" and DTP-CS nanocomposite (DTP-CSNPs) and studied their properties. These studies revealed that these compounds can bind to DNA and have anti-bacterial and cytotoxic activities [9]. Further, DTP and DTP-CSNPs have anti-apoptotic activities against hepatotoxicity and anti-cancer towards HepG2 cell lines [16]. These results encouraged us to prepare DBT and DBT-CSNPs (Figure 1) and study some of their biological properties. Our studies showed that these compounds have an ability to bind to DNA and have anti-bacterial and cytotoxic activities [17]. We are interested in this type of thiophenolato compound because it contains the thiolate $\mathrm{S}$ donors that have $\pi$-acceptor ability and can tune the electron density at the chitosan moiety through $\sigma$ donor and $\pi$ back-bonding characters [18]. It was found that the titanium center enhances the DBT affinity for DNA and changes the binding mechanism. When DBT and its Ti (IV) complex were included in CSNPs, the Ti (IV) center was found to reduce the affinity but not change the mechanism. These results showed that the metal center may not always be important for binding. In this regard, the current study attempted to investigate the therapeutic effect and demonstrated a very important issue, that the metal center may have an important therapeutic effect. Therefore, after the determination of $\mathrm{LD}_{50}$ (the lethal dose: the amount of a compound that causes the death of $50 \%$ of a group of test animals) values of DBT and DBT-CSNPs, the therapeutic effect of DBT and DBT-CSNPs against rat liver injury induced by $\mathrm{CCl}_{4}$ was investigated in detail. The study focused on the determination of the markers of OS, apoptosis, liver functions, lipid profile, and kidney functions besides liver histopathology. Additionally, the effect of these compounds on cell cycle analysis in normal liver (THLE2) and HepG2 cell lines was investigated to determine if these compounds have antitumor activity. 


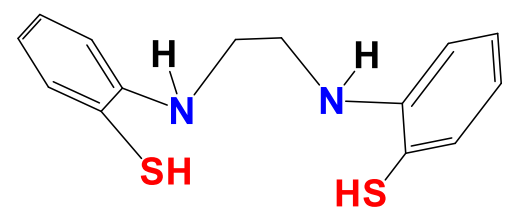

DTP

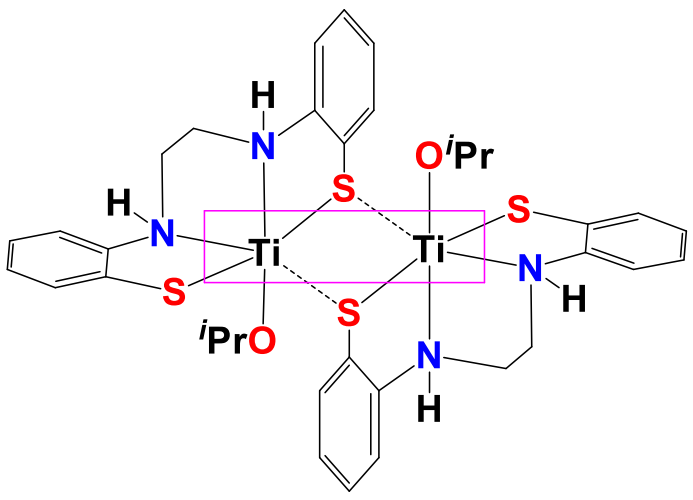

DBT

Figure 1. Structure of Dithiophenolato [DTP] and the Dithiophenolatotitanium (IV)-complex $\left[\left\{\mathrm{Ti}\left(\mathrm{N}_{2} \mathrm{H}_{2} \mathrm{~S}_{2}\right)\left(\mathrm{O}^{i} \mathrm{Pr}\right)\right\}_{\mathrm{x}_{2}}\right]$ [DBT]

\section{Results}

\subsection{Thermal Stability of DBT and DBT-CSNPS}

The data revealed that DBT-CSNPs have a spherical morphology where the particle size was about $\sim 85 \pm 2 \mathrm{~nm}$. The CS nanocomposite has a spherical shape and an average particle size of $75 \pm 3 \mathrm{~nm}$.

\section{2. $L D_{50}$ of DBT and DBT-CSNPS}

The current results showed that the $\mathrm{LD}_{50}$ values of DBT and DBT-CSNPs were about $1350 \mathrm{mg} / \mathrm{kg}$ and $1800 \mathrm{mg} / \mathrm{kg}$, respectively (Table 1).

Table 1. Karber's method for the determination of the $\mathrm{LD}_{50}$ of DBT and DBT-CSNPs in rats.

\begin{tabular}{|c|c|c|c|c|c|c|c|c|c|}
\hline \multirow[b]{2}{*}{ Groups } & \multirow[b]{2}{*}{$\begin{array}{l}\text { Dose } \\
(\mathrm{mg} / \mathrm{kg})\end{array}$} & \multirow[b]{2}{*}{$\begin{array}{l}\text { Dose Dif- } \\
\text { ference } \\
\text { (a) }\end{array}$} & \multirow[b]{2}{*}{$\begin{array}{l}\text { No. of } \\
\text { Rats }\end{array}$} & \multicolumn{3}{|c|}{$\mathrm{LD}_{50}$ of DBT } & \multicolumn{3}{|c|}{ LD $_{50}$ of DBT-CSNPs } \\
\hline & & & & $\begin{array}{l}\text { No. of } \\
\text { Dead }\end{array}$ & $\begin{array}{c}\text { Mean } \\
\text { Mortality } \\
\text { (b) }\end{array}$ & $\begin{array}{l}\text { Product } \\
(\mathbf{a} \times \mathbf{b})\end{array}$ & $\begin{array}{l}\text { No. of } \\
\text { Dead }\end{array}$ & $\begin{array}{c}\text { Mean } \\
\text { Mortality } \\
\text { (b) }\end{array}$ & $\begin{array}{c}\text { Product } \\
(\mathbf{a} \times \mathbf{b})\end{array}$ \\
\hline 1 & 200 & - & 4 & 0 & - & - & 0 & - & - \\
\hline 2 & 400 & 200 & 4 & 1 & 0.5 & 100 & 0 & - & - \\
\hline 3 & 800 & 400 & 4 & 1 & 1 & 400 & 1 & 0.5 & 200 \\
\hline 4 & 1200 & 400 & 4 & 2 & 1.5 & 600 & 1 & 1 & 400 \\
\hline 5 & 2000 & 800 & 4 & 3 & 2.5 & 2000 & 2 & 1.5 & 1200 \\
\hline 6 & 3000 & 1000 & 4 & 4 & 3.5 & 3500 & 4 & 3 & 3000 \\
\hline $\begin{array}{l}\text { Sum of } \\
\text { product }\end{array}$ & & & & & & 6600 & & & 4800 \\
\hline $\mathrm{LD}_{50}$ & & & & & $\begin{array}{l}3000-(660 \\
1350 \mathrm{mg} / \mathrm{kg}\end{array}$ & $4)=$ & & $\begin{array}{l}=3000-(48 \\
1800 \mathrm{mg} / \mathrm{k}\end{array}$ & $4)=$ \\
\hline
\end{tabular}

2.3. Effect of Treatments with DBT, DBT-CSNPS, and Cisplatin on $\mathrm{CCl}_{4}$-Induced Hepatotoxicity 2.3.1. Effect of Different Studied Compounds on OS Markers

The present results revealed that $\mathrm{CCl}_{4}$ injection caused significant $(p<0.05)$ elevations in the malondialdehyde (MDA) level and glutathione reductase (GR) activity associated with a significant $(p<0.05)$ decrease in the glutathione (GSH) level and the activities of total glutathione peroxidase (GPx), glutathione-S-transferase (GST), and superoxide dismutase (SOD) as compared to the control group (Figure 2). 
(a)
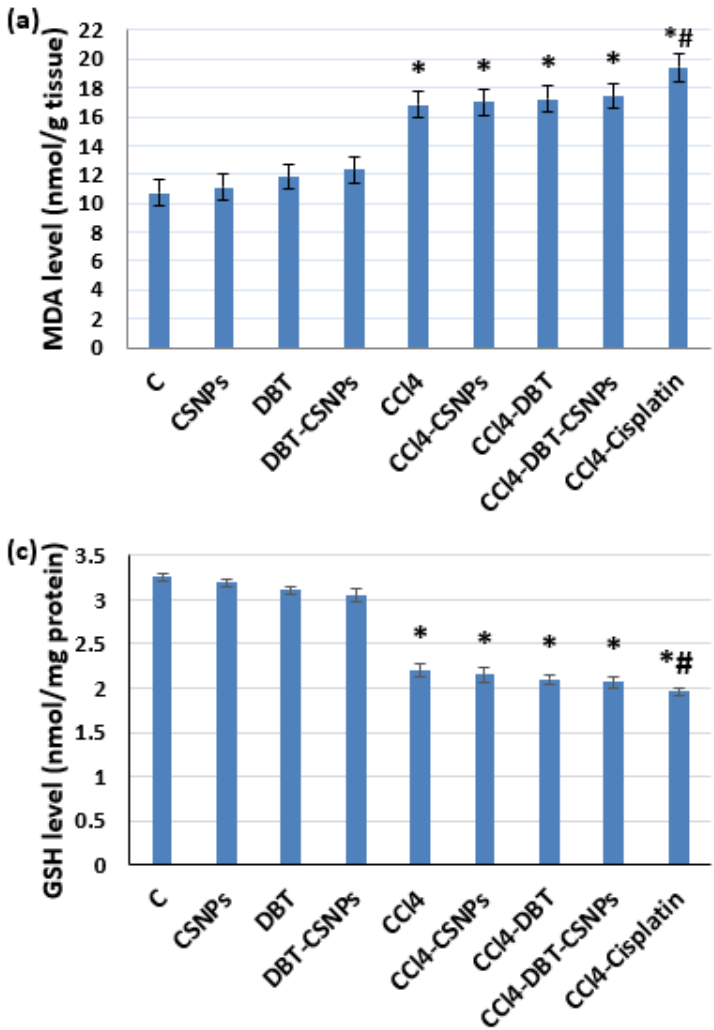

(e)

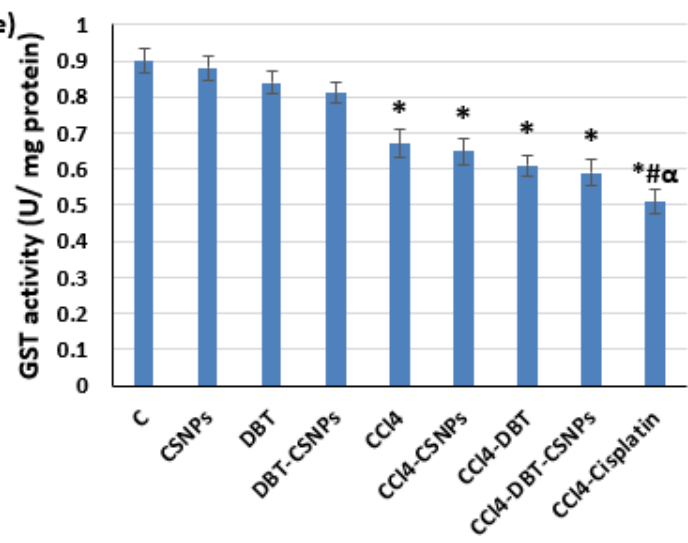

(b)

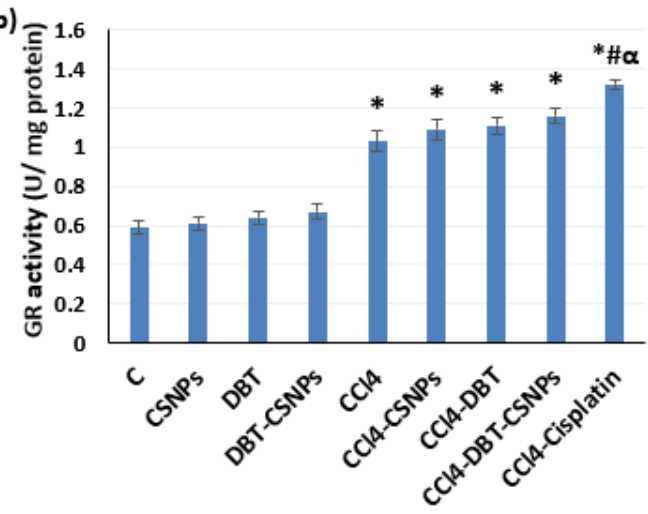

(d)

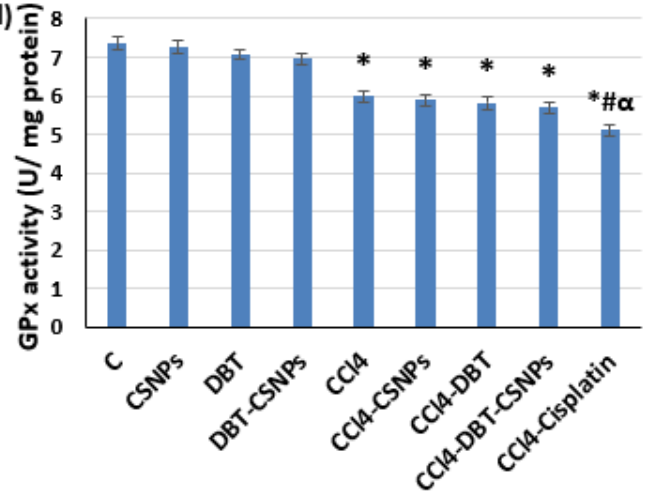

(f) $\widehat{\underline{\underline{c}}} 90$

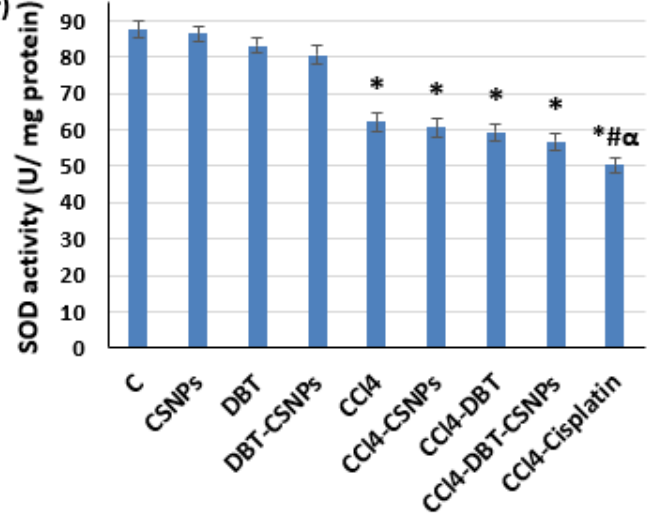

Figure 2. Effect of different studied compounds on OS parameters. (a) malondialdehyde (MDA), (b) glutathione reductase (GR), (c) reduced glutathione (GSH), (d) glutathione peroxidase (GPx), (e) glutathione-S-transferase (GST), and (f) superoxide dismutase (SOD) activities. The values represent the mean \pm SD of eight rats. One-way ANOVA was used ( ${ }^{*} p<0.05$ versus saline control group, $\# p<0.05$ versus $\mathrm{CCl}_{4}$ group $\& \alpha p<0.05$ versus DBT-CSNP-treated group).

In contrast, treatment with DBT and DBT-CSNPs (for 14 days) after $\mathrm{CCl}_{4}$ injection caused non-significant changes (increase or decrease) in the oxidant and antioxidant markers (MDA and GSH levels, beside GPx, GST, and SOD activities) as compared to the $\mathrm{CCl}_{4}$ group. Further, the results showed that CSNP treatment after $\mathrm{CCl}_{4}$ injection caused nonsignificant changes in the oxidant and antioxidant markers when compared to the $\mathrm{CCl}_{4}$ group. However, treatment with cisplatin (for 4 days) after $\mathrm{CCl}_{4}$ injection significantly increased MDA levels; nevertheless, it significantly decreased the antioxidant markers. Administration of CSNPs, DBT, and DBT-CSNPs to healthy rats (for 14 days) caused non-significant changes in the oxidant and antioxidant markers (Figure 2). 


\subsubsection{Effect of Different Studied Compounds on Apoptosis}

The current results revealed that $\mathrm{CCl}_{4}$ administration caused a significant $(p<0.05)$ down-regulation of Bcl-2 expression with significant $(p<0.05)$ up-regulations of Bax and caspase- 8 expressions as compared to the control group (Figure $3 \mathrm{a}-\mathrm{c}$ ). Furthermore, a significant elevation $(p<0.05)$ in the ratio of Bax/Bcl-2 was detected in rats after $\mathrm{CCl}_{4}$ injection compared to the control group (Figure 3d). Further, $\mathrm{CCl}_{4}$ administration increased DNA fragmentation (DNAF) significantly $(p<0.05)$ as compared to the control group (Figure 4, lane 5). In contrast, treatment with DBT and DBT-CSNPs and cisplatin after $\mathrm{CCl}_{4}$ injection caused a significant $(p<0.05)$ elevation in the Bcl-2 expression level with a significant $(p<0.05)$ decline in the expression levels of Bax and caspase- 8 , Bax/Bcl-2 ratio, and DNAF as compared to the $\mathrm{CCl}_{4}$ group (Figures 3 and 4 ). In addition, treatment with CSNPs after $\mathrm{CCl}_{4}$ injection caused non-significant $(p<0.05)$ changes (increase or decrease) in the levels of apoptotic markers (BCl-2, Bax, and caspase-8 expressions as well as the DNAF) with a significant decrease in $\mathrm{Bax} / \mathrm{Bcl}-2$ ratio compared to the $\mathrm{CCl}_{4}$ group (Figures 3 and 4). On the contrary, the administration of CSNPs, DBT, and DBT-CSNPs in healthy rats caused non-significant changes in the levels of apoptotic markers compared to the control group (Figures 3 and 4).

(a)

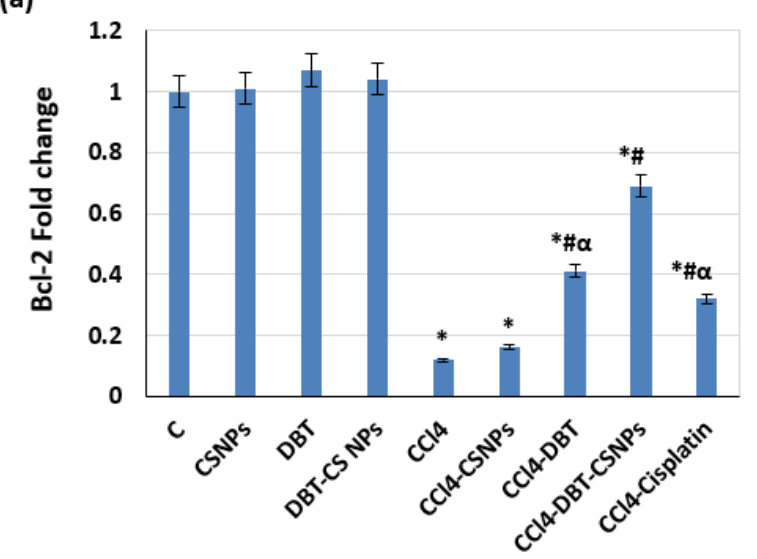

(c)

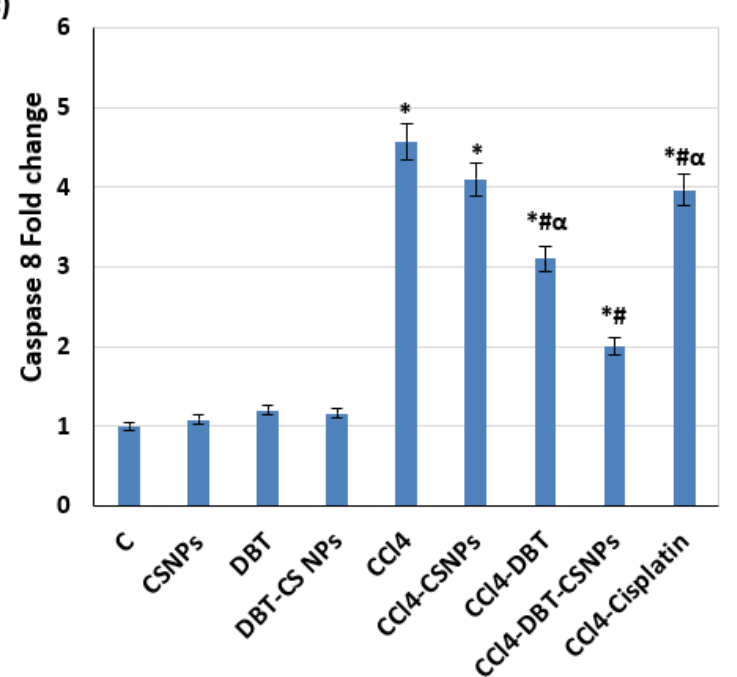

(b)

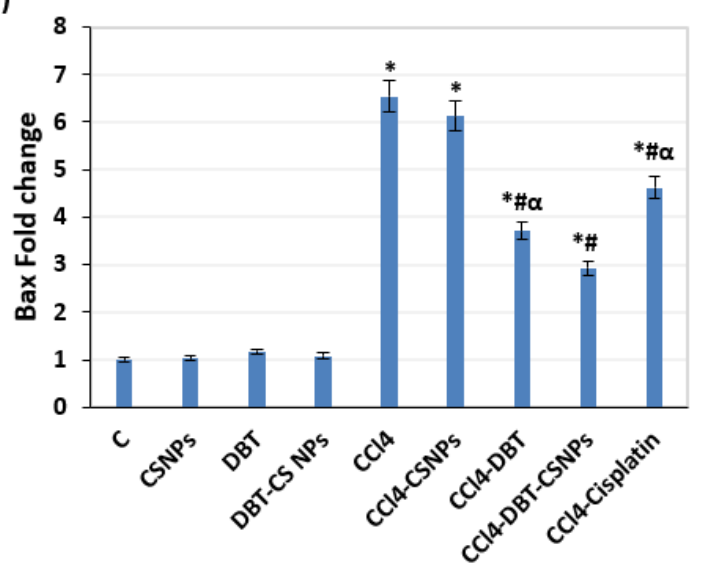

(d)

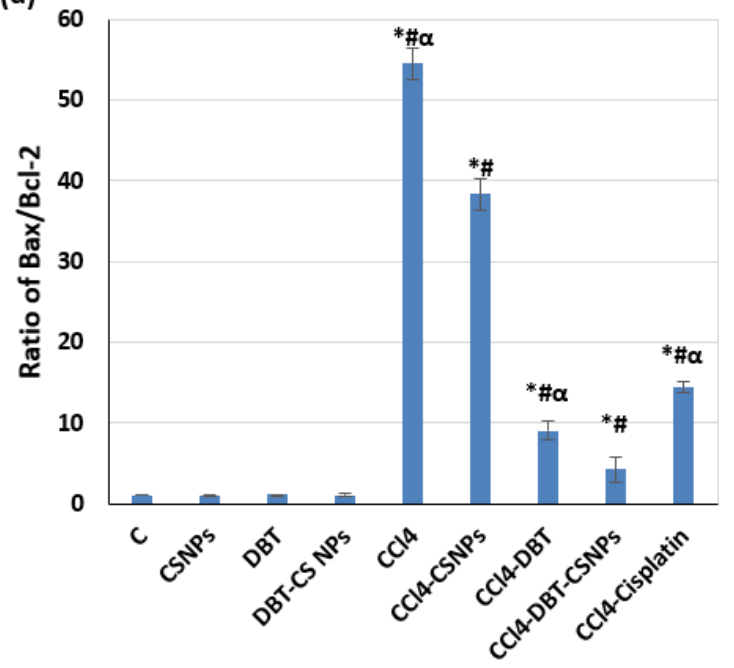

Figure 3. Effect of different compounds on apoptotic markers. (a) The mRNA levels of Bcl-2. (b) The mRNA levels of Bax. (c) mRNA levels of caspase-8. (d) Relative ratio of Bax/Bcl-2 mRNA. Gene expression was normalized to $\beta$-actin. The data are expressed as the mean \pm SD of three rats. One-way analysis of variance (ANOVA) was used ${ }^{*} p<0.05$ versus saline control group, $\# p<0.05$ versus $\mathrm{CCl}_{4}$ group \& $\alpha p<0.05$ versus DBT-CSNP-treated group). 


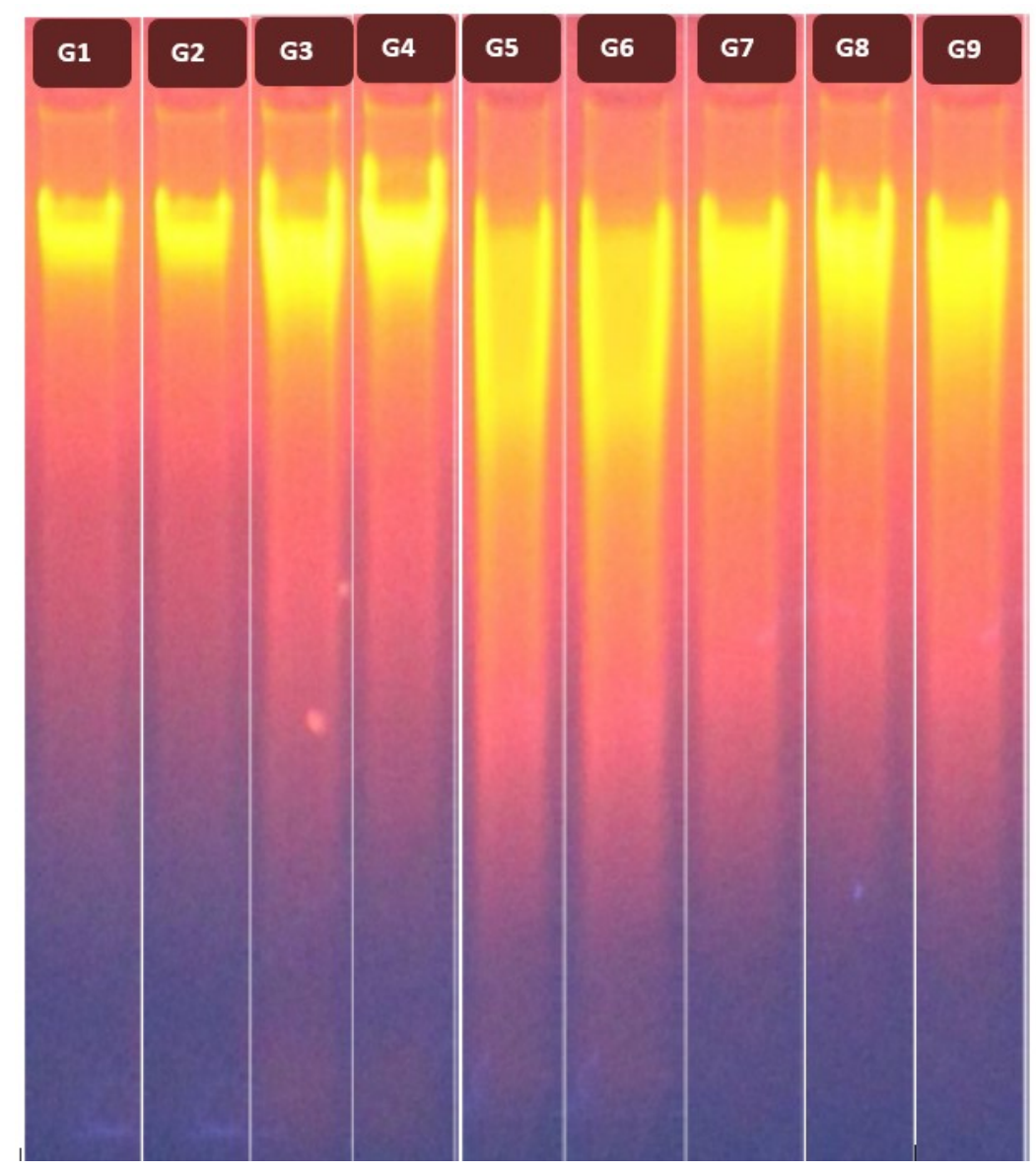

Figure 4. Effect of different compounds on DNAF. Ethidium bromide-stained agarose gel showing fragmentation patterns of the extracted DNA in the studied groups. G1: control, G2: CSNPs, G3: DBT, G4: DBT-CSNPs, G5: $\mathrm{CCl}_{4}$, G6: $\mathrm{CCl}_{4}$-CSNPs, G7: CCl -DBT, G8: $\mathrm{CCl}_{4}$-DBT-CSNPs, and G9: $\mathrm{CCl}_{4}$-cisplatin.

\subsection{Effect of Different Studied Compounds on Liver and Kidney Functions and the Lipid Profile}

The results (Table 2) showed that $\mathrm{CCl}_{4}$ administration caused significant $(p<0.05)$ elevations in the activities of serum alanine aminotransferase (ALT), aspartate aminotransferase (AST), and alkaline phosphatase (ALP), but it substantially reduced the levels of serum albumin, serum total protein (STP), and liver total protein (LTP) compared to the control group. Further, the levels of serum cholesterol, triglyceride (TG), and lowdensity lipoprotein (LDL) were also significantly increased $(p<0.05)$; nonetheless, the serum high-density lipoprotein (HDL) level was significantly decreased $(p<0.05)$ (Table 2$)$. Additionally, $\mathrm{CCl}_{4}$ induced nephrotoxicity where serum urea and creatinine levels were increased significantly $(p<0.05$, Table 2$)$ when compared with the control group. In contrast, treatment with DBT and DBT-CSNPs after $\mathrm{CCl}_{4}$ administration improved liver functions, the lipid profile, and kidney functions to different degrees (Table 2). Treatment with cisplatin after $\mathrm{CCl}_{4}$ improved liver function, the lipid profile, and kidney functions as well as the lipid profile, but to a lesser extent than in those treated with DBT and DBT-CSNPs (Table 2). Treatment with CSNPs after $\mathrm{CCl}_{4}$ administration non-significantly improved liver, kidney functions, and lipid profiles as compared to the $\mathrm{CCl}_{4}$ group. Otherwise, administration of healthy rats with CSNPs, DBT, and DBT-CSNPs, separately, for 14 days induced non-significant changes in the liver and kidney function and lipid profiles as compared to the control group (Table 2). 
Table 2. Effect of different compounds on the liver, kidney functions, and lipid profile.

\begin{tabular}{|c|c|c|c|c|c|c|c|c|c|}
\hline Parameters & $\mathrm{C}$ & CSNPs & DBT & DBT-CSNPs & $\mathrm{CCl}_{4}$ & $\mathrm{CCl}_{4}$-CSNPs & $\mathrm{CCl}_{4}$-DBT & $\begin{array}{l}\mathrm{CCl}_{4} \text {-DBT- } \\
\text { CSNPs }\end{array}$ & $\mathrm{CCl}_{4}$-Cisplatin \\
\hline ALT (U/L) & $117.72 \pm 2.54$ & $118.3 \pm 2.56$ & $120.58 \pm 3.74$ & $122.5 \pm 2.81$ & $265.52 \pm 4.33^{*}$ & $258.31 \pm 3.89 * \alpha$ & $188.33 \pm 2.74^{* \# \alpha}$ & $157.92 \pm 6.09$ *\# & $215.8 \pm 6.8^{* \# \alpha}$ \\
\hline AST (U/L) & $146.19 \pm 3.86$ & $148.3 \pm 3.69$ & $152.78 \pm 5.4$ & $150.7 \pm 4.7$ & $302.1 \pm 4.27^{*}$ & $293.61 \pm 3.89 * \alpha$ & $224.1 \pm 3.25^{* \# \alpha}$ & $187.49 \pm 4.14$ *\# & $259.58 \pm 6.07^{* \# \alpha}$ \\
\hline ALP (U/L) & $252.85 \pm 2.08$ & $254.25 \pm 2.09$ & $257.8 \pm 4.1$ & $255.85 \pm 4.29$ & $456.31 \pm 5.58 *$ & $446.49 \pm 5.41 * \alpha$ & $352.16 \pm 4.05 * \# \alpha$ & $314.9 \pm 3.44$ *\# & $375.2 \pm 5.72 * \# \alpha$ \\
\hline $\mathrm{TP}(\mathrm{g} / \mathrm{dl})$ & $5.89 \pm 0.042$ & $5.87 \pm 0.037$ & $5.80 \pm 0.035$ & $5.84 \pm 0.037$ & $4.99 \pm 0.033^{*}$ & $5.06 \pm 0.039 * \alpha$ & $5.57 \pm 0.045$ *\# & $5.67 \pm 0.035$ *\# & $5.08 \pm 0.095 * \alpha$ \\
\hline $\begin{array}{l}\text { Liver TP (mg/g } \\
\text { tissue) }\end{array}$ & $143.1 \pm 7.38$ & $143.6 \pm 3.92$ & $139.8 \pm 4.34$ & $141.2 \pm 3.77$ & $91.03 \pm 5.88$ * & $87.21 \pm 5.22 * \alpha$ & $105.2 \pm 7.15$ *\# & $121.1 \pm 5.23$ *\# & $83.5 \pm 4.75^{* \alpha}$ \\
\hline Albumin (g/dL) & $4.99 \pm 0.33$ & $4.91 \pm 0.28$ & $4.88 \pm 0.063$ & $4.84 \pm 0.057$ & $3.48 \pm 0.15^{*}$ & $3.57 \pm 0.14 * \alpha$ & $3.91 \pm 0.025$ *\# & $3.77 \pm 0.057$ *\# & $3.35 \pm 0.054 * \alpha$ \\
\hline $\begin{array}{l}\text { Cholesterol } \\
\text { (mg/dL) }\end{array}$ & $88.75 \pm 2.39$ & $90.3 \pm 2.31$ & $91.17 \pm 3.98$ * & $93.08 \pm 2.16$ & $165.44 \pm 2.32 *$ & $160.7 \pm 4.21^{* \alpha}$ & $131.11 \pm 2.61$ *\# & $128.94 \pm 2.57$ *\# & $153.78 \pm 2.39 * \# \alpha$ \\
\hline TG (mg/dL) & $87.49 \pm 1.58$ & $89.2 \pm 1.62$ & $90.08 \pm 2.16$ & $92.07 \pm 2.8$ & $148.03 \pm 2.27^{*}$ & $145.9 \pm 3.26^{* \alpha}$ & $128.75 \pm 1.67 * \# \alpha$ & $123.84 \pm 2.78$ *\# & $133.3 \pm 1.9^{* \# \alpha}$ \\
\hline $\begin{array}{c}\text { LDL- } \\
\text { cholesterol(mg/dL) }\end{array}$ & $55.61 \pm 1.5$ & $56.69 \pm 1.54$ & $61.19 \pm 1.96$ & $58.69 \pm 1.56$ & $93.1 \pm 1.87^{*}$ & $90.2 \pm 2.83 * \alpha$ & $78.28 \pm 2.2^{* \# \alpha}$ & $70.79 \pm 1.45^{* \#}$ & $86.59 \pm 2.01^{* \# \alpha}$ \\
\hline $\begin{array}{l}\text { HDL-cholesterol } \\
\text { (mg/dL) }\end{array}$ & $47.61 \pm 1.45$ & $45.2 \pm 1.42$ & $44.37 \pm 1.51$ & $42.88 \pm 1.86$ & $27.95 \pm 2.09 *$ & $28.9 \pm 1.93^{* \alpha}$ & $40.22 \pm 1.17$ *\# & $41.42 \pm 0.87$ *\# & $33.74 \pm 1.74 * \# \alpha$ \\
\hline Urea $(\mathrm{mg} / \mathrm{dL})$ & $43.79 \pm 2.16$ & $45.2 \pm 2.19$ & $46.74 \pm 2.35$ * & $45.07 \pm 3.96$ & $73.21 \pm 2.98$ * & $71.6 \pm 1.09 * \alpha$ & $65.76 \pm 3.19 * \# \alpha$ & $58.74 \pm 2.35$ *\# & $69.74 \pm 2.26 * \alpha$ \\
\hline
\end{tabular}

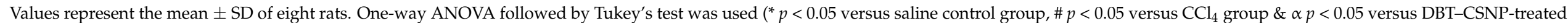
group). 


\subsection{Histopathological Analysis}

Figure 5 (G1-G9) shows the histopathological examination of liver tissues of different studied groups. Treatment with both DBT and DBT-CSNPs after $\mathrm{CCl}_{4}$ injection improved liver histopathology caused by $\mathrm{CCl}_{4}$, elucidating the therapeutic roles of DBT and DBTCSNPs that emphasize the biochemical analysis. However, cisplatin treatment after $\mathrm{CCl}_{4}$ improved liver histopathology caused by $\mathrm{CCl}_{4}$ but to a degree less than the treatment with DBT or DBT-CSNPs. Administration of CSNPs, DBT, and DBT-CSNPs, separately, to the healthy rats had no effect on normal liver architecture.
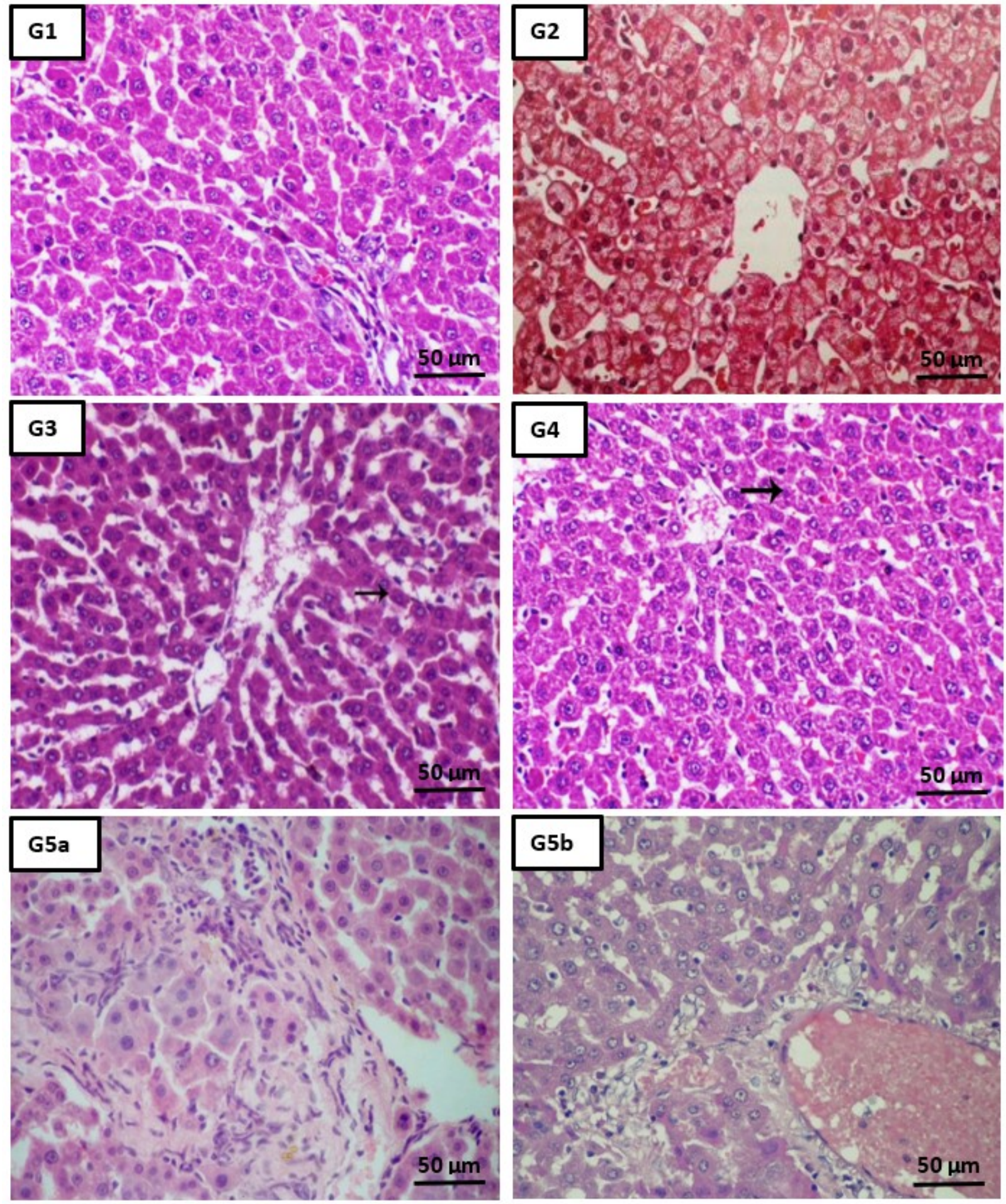

Figure 5. Cont. 

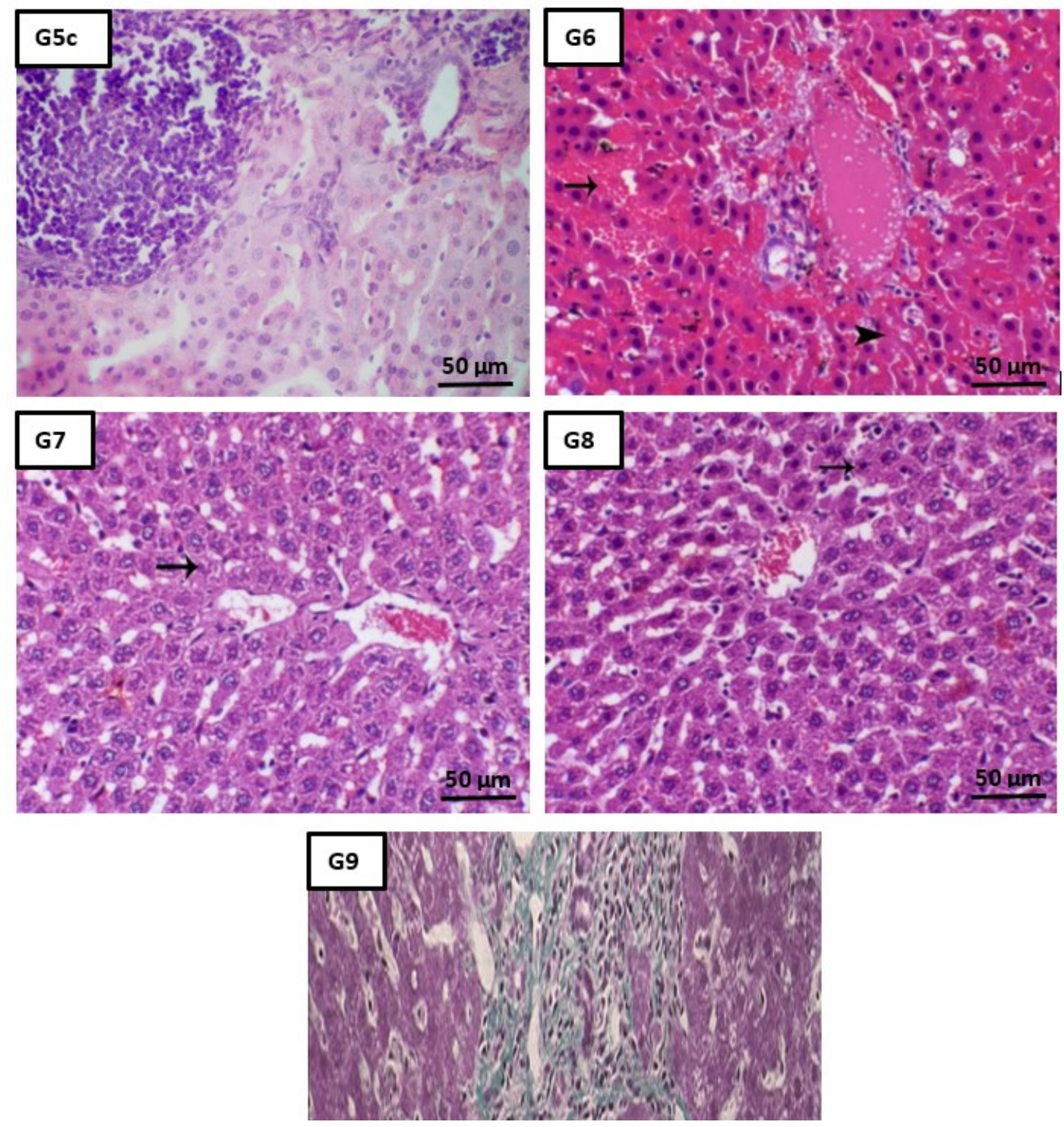

Figure 5. Effect of different studied compounds on the liver histology. Liver tissues from the control group (G1: H\&E, $\times 200$, Scale bar $=50 \mu \mathrm{m}$ ) showed a normal lobular architecture, individual hepatocytes disclosed no pathology, and the portal triad was undetected. Liver tissues of groups CSNPs, DBT, and DBT-CSNPs (G2-G4, respectively: H\&E, $\times 200$, Scale bar $=50 \mu \mathrm{m}$ ) exhibited normal hepatocytes around the central vein. A tissue sample from the intoxicated $\mathrm{CCl}_{4}$ group (G5: H\&E, $\times 200$, Scale bar $=50 \mu \mathrm{m}$ ) revealed cellular infiltration, congestion of central vein, mild portal inflammation, hemorrhage as well as centrilobular hepatic necrosis, and focus of lytic necrosis \& dispersed apoptotic bodies both intra \& extracellular in location. The specimen of CSNP-treated rats (G6: H\&E, $\times 200$, Scale bar $=50 \mu \mathrm{m}$ ) demonstrated congestion of the central vein and hemorrhage (arrow) and centrilobular hepatic necrosis (arrowhead). The specimen of DBT-treated rats (G7: H\&E, $\times 200$, Scale bar $=50 \mu \mathrm{m})$ confirmed a mild degree of hepatic degeneration represented by cell swelling (arrow). On the contrary, the liver tissue of DBT-CSNP-treated rats (G8: H\&E, $\times 200$, Scale bar $=50 \mu \mathrm{m}$ ) revealed a marked decrease in hepatic degeneration unless single cell degeneration (arrow). Moreover, a periportal inflammatory reaction with a degenerated hepatic cord and disrupted cell plates was observed in the tissue of the cisplatin-treated group (G9: H\&E, $\times 200$, Scale bar $=50 \mu \mathrm{m}$ ). These histopathological results revealed the hepatoprotective effects of DBT and DBT-CSNPs, confirming the biochemical analysis. 


\subsection{DBT and DBT-CSNP-Induced Cell Cycle Arrest}

The current results showed that treatment of HepG2 cells with DBT and DBT-CSNPs caused a significant decrease in the population of HepG2 cells in the G0/G1 and S phases when compared with normal cells (Figure 6). Additionally, high populations of HepG2 cells were halted at G2/M checkpoint compared to the untreated cells. Further, the data showed that the cells treated with DBT-CSNPs showed the lowest levels in the G0/G1 and $S$ phases with the highest in the G2/M phase as compared to those treated with DBT (Figure 6).

(a)
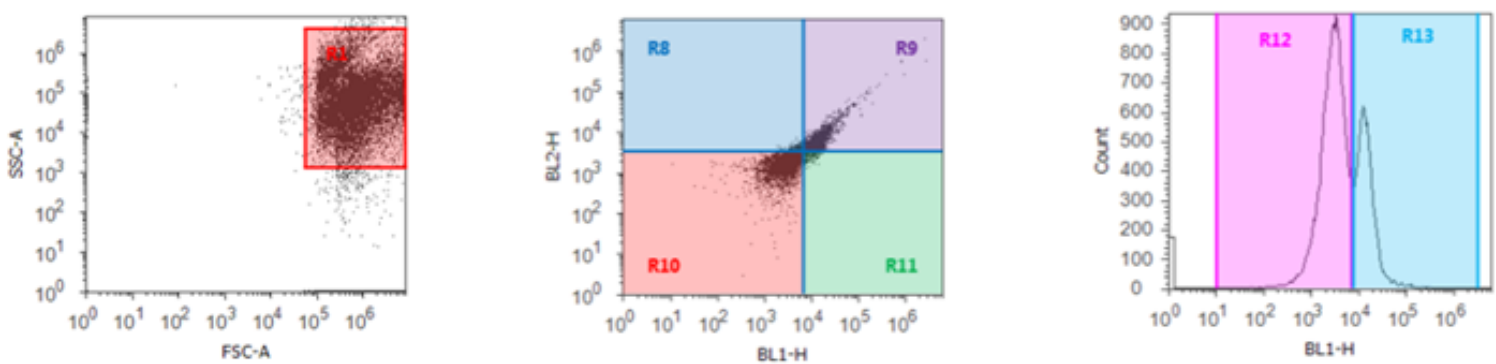

G0/G1 $=60 \pm 2.83 \%, S=16 \pm 1.04 \%, G 2 / M=24 \pm 1.23 \%$

(b)
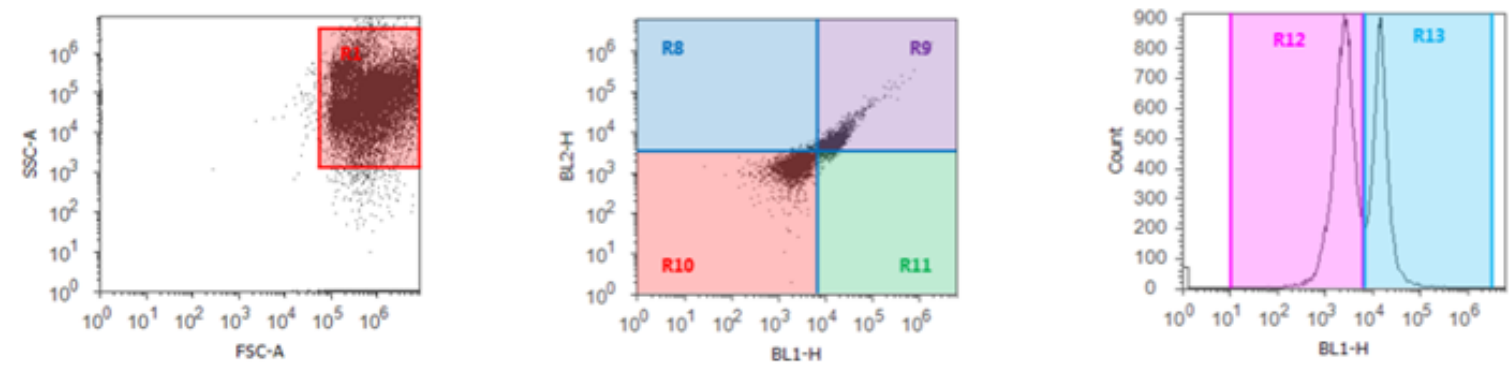

G0/G1 $=42 \pm 2.03 \%, S=11 \pm 0.95 \%, G 2 / M=47 \pm 2.80 \%$

(c)
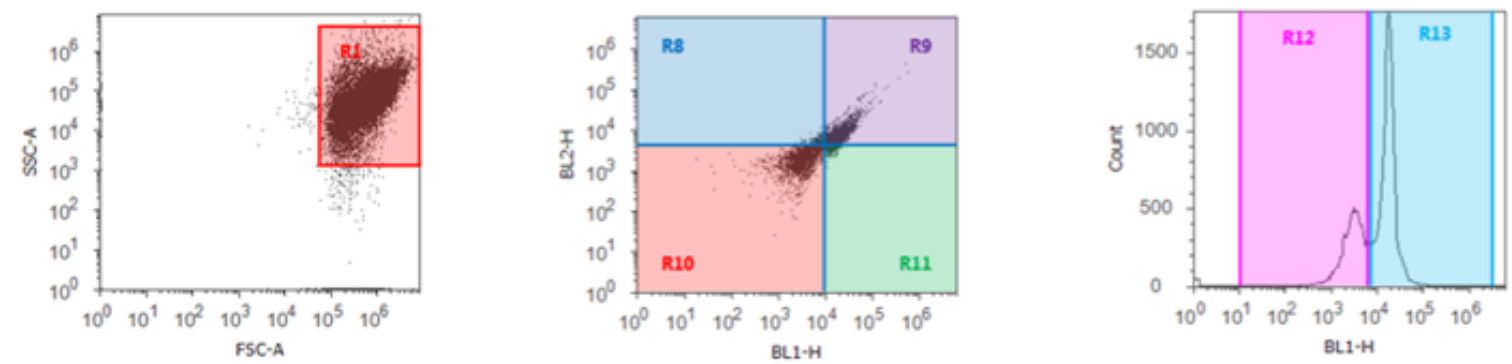

G0/G1 $=15 \pm 1.11 \%, S=8 \pm 0.84 \%, G 2 / M=77 \pm 2.97 \%$

Figure 6. Cont. 
(d)

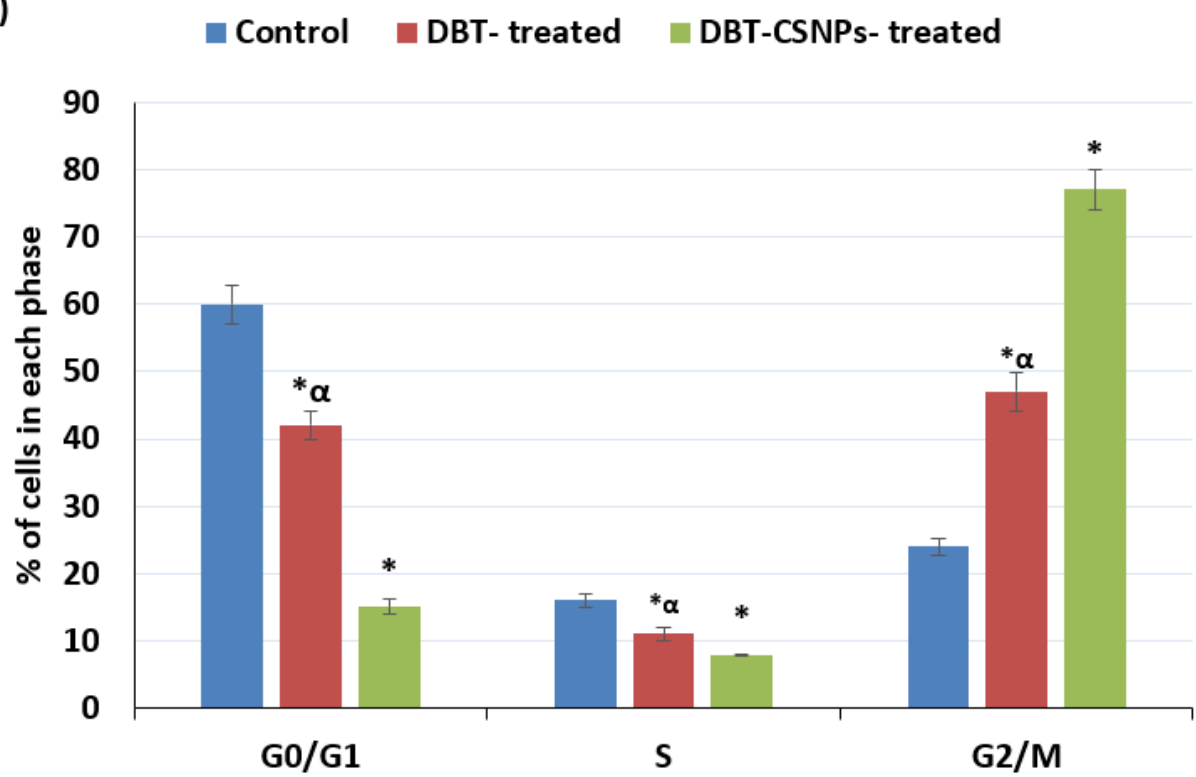

Figure 6. Flow cytometric analysis of control and treated HepG2 cells. (a) Control, (b) DBT-treated HepG2 cells, and (c) DBT-CSNP-treated HepG2 cells. The values represent the mean $\pm \mathrm{SD}(n=3)$. (d) Represents $\%$ of cells in each phase. One-way ANOVA followed by Tukey's test was used (* $p<0.05$ versus saline control \& $\alpha p<0.05$ versus DBT-CSNPs).

\section{Discussion}

DBT-CSNPs have a spherical morphology with an average particle size of $\sim 85 \pm 2 \mathrm{~nm}$, while the CS nanocomposite has a spherical shape and an average particle size of $75 \pm 3 \mathrm{~nm}$. The presence of DBT in the DBT-CSNPs was found to increase the thermal stability of the composite material in comparison to DBT [17]. In our previous studies, the TEM images revealed the compatibility of DBT-CS surface adsorption through the time of reaction. This interaction may be related to the hydroxyl groups that are present on the surface of DBT, as these hydroxyl groups may form hydrogen interactions with the amino groups at certain sites along the CS nanoparticles. Furthermore, the SEM spectrum images confirmed the TEM morphology and showed that DBT-CS particles are linked as bundles with a leaf structure. Further, energy-dispersive X-ray (EDAX) analyses revealed the presence of the NK, OK, SK, and TiK atoms in the elemental composition of the prepared nanocomposite [17]. The DBT-CS nanocomposite has major CS nanoparticle components and a minor amount of DBT.

Additionally, the $\mathrm{LD}_{50}$ values of DBT and DBT-CSNPs were about 1350 and $1800 \mathrm{mg} / \mathrm{kg}$, respectively. Previous studies revealed that the $\mathrm{LD}_{50}$ values of oral titanium tetrachloride and oral titanium oxide nanoparticles $\left(\mathrm{TiO}_{2} \mathrm{NPs}\right)$ were $1780 \mathrm{mg} / \mathrm{kg}$ and greater than $12 \mathrm{~g} / \mathrm{kg}$, respectively [19]. The $\mathrm{LD}_{50}$ values of DTP and CSNP-DTP were about 2187.5 and $1462.5 \mathrm{mg} / \mathrm{kg}$, respectively [16]. In this study, the rat hepatotoxicity induced by $\mathrm{CCl}_{4}$ administration was treated with safe doses of DBT and DBT-CSNPs ( 4.5 and $3 \mathrm{mg} / \mathrm{kg} \mathrm{BW}$, respectively). The doses of DBT and DBT-CSNPs were chosen to be close to the dose of cisplatin, which is given to patients (4 mg/ $\mathrm{kg} \mathrm{BW}$ ). Generally, cisplatin is given for four days only, but it causes side effects, while DBT and DBT-CSNPs are given for a long period (14 days) since titanium is distinguished by its nontoxicity.

The present study demonstrated that repeated administration with $\mathrm{CCl}_{4}$ induced hepatotoxicity and liver damage via the elevation of OS and apoptosis. This led to the disturbance in liver functions as liver enzymes were elevated in the blood circulation and the lipid profile changed. These results are in harmony with the histological results. In contrast, treatment of rats with DBT and DBT-CSNPs after $\mathrm{CCl}_{4}$ mitigated the hepatotoxicity and liver damage to different degrees through the reduction of apoptosis caused by $\mathrm{CCl}_{4}$, which improved liver functions, the lipid profile, and liver histopathology. Interestingly, the 
DBT-CSNP treatment showed better effects than treatment using DBT and cisplatin, which is used as a standard drug. All these conclusions are discussed in detail as follows. The data of the current study demonstrated that $\mathrm{CCl}_{4}$ administration induced hepatotoxicity, resulting in severe liver damage as revealed from the histopathological results, which were confirmed by the biochemical results comprising the markers of liver functions, the lipid profile, and apoptosis in liver tissues. The mechanism of $\mathrm{CCl}_{4}$-induced hepatotoxicity may be related to the harmful effect of $\mathrm{CCl}_{4}$ and its extremely reactive metabolites $\left(\mathrm{CCl}_{3}{ }^{*}\right.$ and $\mathrm{CCl}_{3} \mathrm{O}_{2}{ }^{*}$ ). These free radicals induced OS as demonstrated from the change in the MDA level and GR activity with lower levels of the antioxidants (GSH, GPx, GST, and SOD). MDA is the main product of peroxidation of polyunsaturated fatty acids and its elevated content is a significant indicator of lipid peroxidation [20].

The elevation in the peroxidation of the mitochondrial membrane increased membrane permeability and altered calcium homeostasis, resulting in the loss of cell integrity that contributed to cell death [5,6]. GR plays a key role in cellular defense against OS by preventing the accumulation of oxidized glutathione (GSSG) and thus maintaining the redox state. Therefore, the increase in GR activity after $\mathrm{CCl}_{4}$ administration possibly reflects an adaptation to oxidative condition and this agrees with a previous study [1]. In contrast, free radical scavengers (GSH, GPx, GR, GST, and SOD) protect the biological systems from the deleterious effects of free radicals [21]. GSH plays an important role against lipid peroxidation induced by $\mathrm{CCl}_{4}$ through covalent binding to ${ }^{\circ} \mathrm{CCl}_{3}$ and $\mathrm{CCl}_{3} \mathrm{OO}{ }^{\bullet}$ radicals [22]. Additionally, GSH acts as a cofactor for GPx and as a nucleophilic scavenger of numerous compounds [22]. In this study, depletion of the GSH level after $\mathrm{CCl}_{4}$ administration could contribute to the stimulation of lipid peroxidation [2,22].

Additionally, SOD is the body's first line of protection against superoxide radicals [19,20], where it catalyzes the dismutation of the superoxide radical into ordinary molecular oxygen and $\mathrm{H}_{2} \mathrm{O}_{2}$ [20]. GPx, a selenium-containing enzyme, is the second line of protection against hydroperoxides by catalyzing the reduction of $\mathrm{H}_{2} \mathrm{O}_{2}$ and lipid peroxides, in the presence of GSH, to water and lipid alcohols, respectively, while GSH is transformed into GSSG [2,22]. Furthermore, GSTs are considered as major phase II detoxification enzymes and are mainly present in the cytosol since they catalyze the conjugation of GSH with a wide range of electrophilic substances. Subsequently, the reduction in the activities of antioxidant enzymes may be related to their inhibition by $\mathrm{CCl}_{4}$ and its reactive metabolites through direct interaction with the enzyme molecules. Further, GSH depletion led to the inhibition of GPx and GST. Additionally, SOD inhibition resulted from the oxidation of the cysteine residues in its molecules [3,23].

Apoptosis is a form of cell death where the programmed concatenation of the process results in the removal of superfluous cells without releasing deleterious substances into the surrounding area [24]. Apoptosis is tightly regulated by particular genes, including several pro-and anti-apoptotic proteins [24,25]. Proteins of the Bcl-2 family exert different effects; for example, Bcl-2 and Mcl-1 are anti-apoptotic proteins, while the white B-cell lymphoma X protein (Bax, Bad and Bak) exhibits pro-apoptotic effects. Dysfunction of apoptosis renders the cancer cell to become resistant to treatment as well as promoting tumorigenesis [25,26]. Bax activation elicits cytochrome-c release, procaspase-3 activation, and Poly (ADP-ribose) polymerase cleavage through the stimulation of Apaf-1 (apoptosis protease activating factor-1), which leads to the induction of the apoptosis response and cell death [27]. Caspase-8 is a cysteine protease that initiates apoptotic signaling via the extrinsic pathway. Activation of caspase- 8 induces apoptosis through the activation of caspase- 3 directly or activation of Bax, which in turn activates caspase- 3 , resulting in the cleavage of essential substrates for cell viability, inducing cell death $[27,28]$. Furthermore, cleavage of chromosomal DNA into oligonucleosomal size fragments is an essential part of apoptosis $[24,25,29]$.

The current results showed that $\mathrm{CCl}_{4}$ administration induced the regulation of proapoptotic proteins Bax and caspase-8, with down-regulation of anti-apoptotic protein Bcl-2. Changes in Bcl-2 and Bax levels stimulated a change in the ratio of $\mathrm{Bax} / \mathrm{Bcl} 2$ that 
became much higher than that of the control group. Elevation in the Bax/Bcl-2 ratio caused permeabilization of the outer membrane of the mitochondria, releasing cytochrome $\mathrm{C}$ into the cytoplasm $[4,30]$. Furthermore, the elevation in caspase- 8 after $\mathrm{CCl}_{4}$ administration stimulated apoptosis via the activation of caspase-3 directly or indirectly [27,29].

Moreover, the elevation in $\mathrm{ROS}$ after $\mathrm{CCl}_{4}$ administration induces the elevation of p53 signaling, which in turn stimulates Bax expression; nonetheless, it blocks Bcl-2 expressions (i.e., the ratio of $\mathrm{Bax} / \mathrm{Bcl}-2$ was elevated), leading to apoptosis [31,32]. In addition, the current results revealed that $\mathrm{CCl}_{4}$ induced apoptosis via the induction of DNAF where its level was increased significantly compared to the control group. This may be related to the reaction of $\bullet \mathrm{CCl}_{3}$ and $\mathrm{CCl}_{3} \mathrm{OO} \bullet$ and other ROS with DNA, forming adducts $[1,23]$ that activated pro-apoptotic factors, promoting apoptosis and cell death [1,2,33]. These results are consistent with previous studies, which demonstrated that $\mathrm{CCl}_{4}$ induced rat liver fibrosis through the activation of apoptosis $[4,30,34]$.

In general, the present results showed that $\mathrm{CCl}_{4}$ administration induced $\mathrm{OS}$ and apoptosis, and this led to acute liver injuries wherever these results were in unison with the histopathological results. Additionally, liver injuries after $\mathrm{CCl}_{4}$ administration were assured by the elevation of the activities of liver enzymes (AST, ALT, and ALP) and the lipid profile (TG, TC, and LDL cholesterol) in serum with a decrease in albumin, LTP, STP, and HDL cholesterol.

In contrast, treatment of rats with DBT and DBT-CSNPs (for 14 days) after $\mathrm{CCl}_{4}$ administration caused an amelioration of the hepatic histopathology as revealed by the liver architecture. These results are evidenced by the amelioration of liver functions and lipid profile. The levels of ALT, AST, and ALP became lower than those in $\mathrm{CCl}_{4}$ group, while LTP and STP were improved. Further, the levels of TG, total cholesterol, and LDL cholesterol became lower than those of the $\mathrm{CCl}_{4}$ group, while HDL cholesterol became greater. Additionally, the renal functions were improved as shown by the levels of urea and creatinine, which became lower than those of the $\mathrm{CCl}_{4}$ group. All these positive results can be attributed to the therapeutic effects of DBT and DBT-CSNPs, which diminished liver injuries induced by $\mathrm{CCl}_{4}$ via the reduction of apoptosis induced by $\mathrm{CCl}_{4}$ as demonstrated by the current results. First, treatment with DBT and DBT-CSNPs caused non-significant changes in the OS in the liver as compared to the $\mathrm{CCl}_{4}$ group, where MDA as an oxidant and GR activity were insignificantly increased; nevertheless, the antioxidants (GSH, GPx, GST, and SOD) were insignificantly decreased. Non-significant changes in OS induced by these treatments did not adversely affect the liver as shown by the results of liver functions, the lipid profile, and liver histopathology as mentioned above, but improved them. The non-significant elevation in the MDA level may be related to the metabolites of the DBT and DBT-CSNPs $\left(\mathrm{TiO}_{2}\right.$ and $\mathrm{TiO}_{2} \mathrm{NPs}$, respectively). $\mathrm{TiO}_{2}$ and $\mathrm{TiO}_{2} \mathrm{NPs}$ promote the generation of ROS such as $-\mathrm{O}_{2} \bullet$ and $\mathrm{H}_{2} \mathrm{O}_{2}$ [35]. Interestingly, the previous studies showed that the thiol groups in the DBT and DBT-CSNPs play an important role in the reduction of $\mathrm{H}_{2} \mathrm{O}_{2}$. The thiol groups are oxidized in the presence of $\mathrm{H}_{2} \mathrm{O}_{2}$ formation (O-S-O) leading to the non-significant elevation in the MDA level compared with $\mathrm{CCl}_{4}$ [36]. On the contrary, SOD and GPx are zinc- and selenium- dependent enzymes, respectively. Therefore, the reduction in their activities in the present study may be due to the replacement of zinc and selenium ions with Ti ions, which resulted in the inhibition of these enzymes. Further, Ti ions may bind with the sulfhydryl groups of GSH, resulting in diminished GSH levels and thus the inhibition of GPx and GST activities [37]. In general, the results revealed that DBT-CSNPs had a greater effect than DBT and this may be due to the physicochemical properties of the nanoparticles that are distinguished by a nano-size, resulting in increased surface area/unit mass and the surface property effects facilitating their passage through cell membranes hydrolyzed into $\mathrm{TiO}_{2} \mathrm{NPs}$ and interruption of the biological systems [36-39]. The current results are consistent with the previous studies, which showed that the nanoparticles motivate OS, and this process is dose-dependent $[40,41]$.

The present results revealed that treatment of rats with cisplatin for 4 days after $\mathrm{CCl}_{4}$ injection significantly increased the OS as demonstrated by the elevation of lipid 
peroxidation and reduction of antioxidant parameters leading to liver damage, resulting in the elevation of serum liver enzymes and changing the lipid profile. These results coincide with previous studies [42-44].

The administration of CSNPs, DBT-CSNPs and DBT to healthy rats for 14 days caused non-significant changes in the levels of OS markers (MDA, GR, GSH, GPx, GST, and SOD) when compared to the control group, leading to non-significant effects in the markers of the lipid profile and liver and kidney functions. Although DBT-CSNPs had a greater effect than DBT, they did not change the liver histology.

On the contrary, treatment of rats with DBT and DBT-CSNPs, as well as cisplatin after $\mathrm{CCl}_{4}$ caused a significant $(p<0.05)$ elevation in the Bcl-2 expression level with a significant $(p<0.05)$ decline in the levels of DNAF, Bax, and caspase- 8 expressions besides the Bax/Bcl2 ratio as compared to the $\mathrm{CCl}_{4}$ group. The reduction in the Bax/Bcl-2 ratio led to the stabilization of the mitochondrial membrane and prevented the release of cytochrome $C$, resulting in the lowering of apoptosis. The decreased Bax/Bcl-2 ratio led to the stabilization of the mitochondrial membrane and prevented the release of cytochrome $\mathrm{C}$, resulting in diminished apoptosis.

In addition, the administration of rats with CSNPs only after $\mathrm{CCl}_{4}$ injection induced non-significant changes (increase or decrease) in all markers of apoptosis as compared to the $\mathrm{CCl}_{4}$ group, indicating that DBT-CSNP treatment after $\mathrm{CCl}_{4}$ was mainly related to the effect of DBT not CSNPs. Interestingly, treatment with DBT-CSNPs showed a greater effect than the DBT treatment, and this may be due to the variation in the physicochemical properties of these compounds and their metabolites as previously mentioned.

The results of the present study agree with the previous studies, which reported that $\mathrm{TiO}_{2} \mathrm{NPs}$ have anti-apoptotic action greater than $\mathrm{TiO}_{2}$, and their effects are dose-, period-, and cell type-dependent [30].

Moreover, treatment with DBT and DBT-CSNPs for 14 days after $\mathrm{CCl}_{4}$ gave better results than the treatment with cisplatin (dose) for four days (the period of treatment for cancer patients with this drug). As indicated by the current results, cisplatin treatment significantly increased OS, lipid peroxidation, and liver damage, resulting in the elevation of serum liver enzymes and changing the lipid profile and kidney functions. All these adverse effects that resulted from cisplatin treatment are in accordance with previous studies [45,46]. In contrast, 14-day DBT and DBT-CSNP treatment increased the OS nonsignificantly, and thus there were non-significant changes in the liver functions, lipid profile, and kidney functions.

Moreover, treatment with DBT and DBT-CSNPs for 14 days after $\mathrm{CCl}_{4}$ gave better results than the treatment with cisplatin (dose) for four days. As indicated by our results, cisplatin treatment significantly increased OS and lipid peroxidation as compared with $\mathrm{CCl}_{4}$, illustrating that the total lipid peroxidation was caused by $\mathrm{CCl}_{4}$ and cisplatin. Therefore, treatment with DBT and DBT-CSNPs improved the liver functions and lipid profile and kidney functions.

However, cisplatin treatment improved liver functions and the lipid profile, but to a lesser degree than DBT and DBT-CSNPs. Further, cisplatin treatment caused nonsignificant improvement in kidney functions compared to the $\mathrm{CCl}_{4}$ group. These results agree with the previous studies, which showed that the clinical use of cisplatin is strictly limited, particularly by dose-dependent side effects $[1,30]$. Although cisplatin is one of the majority effective chemotherapeutic drugs for the treatment of different cancers [47], it causes nephro-, neuro-, cardio-, and hepatotoxicity due to its accumulation in the liver, kidneys, and other organs, generating free radicals resulting in OS, and thus inducing damage to the liver and kidneys, as well as different organs [43,48]. Furthermore, the results showed that the administration of DBT, DBT-CSNPs, or CSNPs to healthy rats caused non-significant changes in apoptosis, where all studied markers were non-significantly changed as compared to the control group.

DBT and DBT-CSNPs are featured by their antitumor activities against HepG2 cells. Cell growth and proliferation are involved in cell cycle organization, and an imbalance 
between them induces apoptosis that is implicated in the growth and progression of most tumors [47]. Our previous study showed that DBT and DBT-CSNPs have cytotoxic effects, and they can link to DNA. Therefore, the present study attempted to evaluate their anti-proliferative effect toward the HepG2 cell line through cell cycle analysis to determine whether these compounds have antitumor activities. Consequently, the present results revealed that treatment with DBT and DBT-CSNPs caused a significant decrease in the population of HepG2 cells in the G0/G1 and S phases when compared to the normal cells. This elucidates that these compounds overlapped with DNA synthesis and disrupted the advancement of the cell cycle, resulting in apoptosis. Moreover, these compounds arrested high populations of HepG2 cells at the G2/M checkpoint when compared with untreated cells. This indicates that the cell cycle arrest resulted in disruption of the tubulinmicrotubule equilibrium and allowed the time for DNA repair or allowed cells to survive through persistent DNA damage. Generally, DBT and DBT-CSNPs have antitumor activities involved in cell division and stopping the uncontrolled proliferation of cancer cells besides initiating apoptosis, and this is considered to be a significant strategy. The antiproliferative and apoptotic activities of DBT and DBT-CSNPs perhaps may be due to the cytotoxicity of these complexes and their metabolites $\mathrm{TiO}_{2}$ and $\mathrm{TiO}_{2} \mathrm{NPs}$, respectively. Previous studies showed that $\mathrm{TiO}_{2} \mathrm{NPs}$ induce OS in HepG2 cells, DNAF, and p53 activation, leading to apoptosis [38,40]. Further, it has been reported that a drug delivery system promotes clinical conclusions by enhancing permeability and its rate, qualifying targeted delivery, and simple distribution of the drug, leading to amelioration of the efficacy of several drugs [49].

In general, our results revealed that DBT-CSNPs and DBT treatments decreased rat liver apoptosis induced by $\mathrm{CCl}_{4}$, resulting in the improvement of liver architecture and functions besides reducing nephrotoxicity. In addition, DBT-CSNPs and DBT had anticancer activities against HepG2 cell lines through the prevention of their proliferation by increasing apoptosis via arresting the cell cycle in the G2/M phase. These results indicate that the DBT-CSNPs and DBT are selective, and this means that they have an ability to distinguish between liver injuries and cancer cell lines. The current results agree with the previous studies, which reported that the effect of drugs and xenobiotics in cell lines and in vivo are different from each other [50,51].

\section{Materials and Methods}

\subsection{Chemicals}

Bound HepG2 was obtained from the American Type Culture Collection (ATCC, Manassas, VA, USA). GIBCO ${ }^{\circledR}$ Minimum Essential Medium (MEM) was purchased from GIBCO (Grand Island, New York, NY, USA). Dulbecco's Phosphate-Buffered Saline medium and L-glutamine were obtained from Invitrogen (Carlsbad, CA, USA). Trypsin-EDTA, penicillin, and streptomycin were purchased from Thermo Fisher Scientific (Waltham, MA, USA). Cisplatin, $\mathrm{CCl}_{4}$, Dimethyl sulfoxide (DMSO), and other analytical-grade chemicals were purchased from Sigma Aldrich (St. Louis, MO, USA). The kits for the methyl thiazolyl tetrazolium (MTT) assay and RNA extraction were obtained from Eugene, Oregon, USA, and Thermo Scientific, Fermentase, respectively. All other analytical grade chemicals were obtained from Sigma (St. Louis, MO, USA) and Merck (Darmstadt, Germany). All dilutions were made with high-purity deionized water, obtained from a Milli- $Q^{\circledR}$ system (Merck Chemicals GmbH, Darmstadt, Germany).

\subsection{Animals}

Adult male Sprague-Dawley rats (number: 120 and weighing 110-140 g) were obtained from the experimental animals Breeding Centre of the Holding Company for Biological Products and Vaccines (Helwan, Cairo, Egypt). They were housed in stainless cages under standard laboratory conditions of $50 \pm 5 \%$ air humidity, a 12-h light/dark cycle, and at a room temperature of $23 \pm 2{ }^{\circ} \mathrm{C}$. Rats received a standard laboratory diet and tap drinking water and were left for two weeks as an adaptation period. All animal 
methodology followed the Institutional Animal Care and Use Committee (IACUC) and was approved through the Committee of the Animal Care and Use at Alexandria University (Ethical approval reference number: AU 042006202 02, approved on 20/06/2020).

\subsection{Preparation of $D B T-C S N P S$}

DBT $\left[\mathrm{Ti}\left(\mathrm{N}_{2} \mathrm{Me}_{2} \mathrm{~S}_{2}\right)\left(\mathrm{O}^{\mathrm{i}} \mathrm{Pr}\right)_{2}\right]$ was synthesized from the thiolate-amine ligand $\mathrm{N}_{2} \mathrm{Me}_{2} \mathrm{~S}_{2}{ }^{2-}$, containing the $\mathrm{N}_{1} \mathrm{~N}^{\prime}$-dimethylethylenediamine backbone and titanium tetra (iso-propoxide) in methanol as a solvent. The crystal structure exhibited twisted octahedral geometry with respect to titanium with the two isopropoxo groups being cis to each other and to the two tetradentate ligand thiolate groups. The ligand's two tertiary amine atoms are cis to each other and essentially trans to terminal oxo groups [18]. CSNPs were prepared using ionic gelation techniques using chitosan and sodium tripolyphosphate (TPP). DBT-CSNPs were prepared from DBT, sodium tripolyphosphate, and chitosan [17]. In brief, sodium tripolyphosphate solution was added to the chitosan solution, left at $25^{\circ} \mathrm{C}$ for $12 \mathrm{~h}$, after which DBT was added, left for $40 \mathrm{~min}$, and the solvent was removed at $40^{\circ} \mathrm{C}$. Characterization of DBT-CSNPs was examined by a High-Resolution Transmission Electron Microscope (HR-TEM), Scanning Electron Microscope (SEM) with an EDX detector, X-Ray Diffraction (XRD), Fourier transform infrared (FT-IR), and Thermographymetric Analysis (TGA) [17].

\subsection{Determination of the $L D_{50}$ Values of DBT and DBT-CSNPs}

Initially, the $\mathrm{LD}_{50}$ values of DBT or DBT-CSNPs were estimated mathematically using the values of IC50 $(\mu \mathrm{g} / \mathrm{mL})$ according to the regression formula obtained from the Interagency Coordinating Committee on the Validation of Alternative Methods: (ICCVAM) $\log \mathrm{LD}_{50}(\mathrm{mg} / \mathrm{kg})=0.372 \operatorname{logs} \mathrm{IC}_{50}(\mu \mathrm{g} / \mathrm{mL})+2.024$ [52]. The $\mathrm{LD}_{50}$ values obtained theoretically facilitate the determination of $\mathrm{LD}_{50}$ in vivo. For determination of the $\mathrm{LD}_{50}$ of DBT and DBT-CSNPs, 48 rats were divided into 12 groups, and six doses of DBT and DBTCSNPs, separately, were dissolved in 2\% DMSO $(200,400,800,1200,2000$, and $3000 \mathrm{mg} / \mathrm{kg})$ and were used for intraperitoneal (IP) injection at once. Animals were examined for any abnormal clinical signs and behavioral changes for $24 \mathrm{~h}$. The dead rats in each group were recorded (\% dead), and the $\mathrm{LD}_{50}$ value was calculated according to the following equation Kärber [52].

$$
\mathbf{L D}_{50}=\mathbf{L D}_{100}-\sum(\mathbf{a} \times \mathbf{b}) / n
$$

where $\mathrm{LD}_{100}=$ the lethal dose triggering $100 \%$ mortality; $\mathrm{a}=$ dose difference: the discrepancy between two successive doses of the administered substance; $b=$ mean mortality: the average number of dead rats in two consecutive doses, and $n=$ group population: the total number of rats per group.

\subsection{Biological Effects of DBT, DBT-CSNPS, and Cisplatin on $C C_{4}$-Induced Liver Injuries}

The doses of DBT and DBT-CSNPs were chosen to be safe, with respect to their $\mathrm{LD}_{50}$ values where these doses approached that of cisplatin. DBT and DBT-CSNPs and CSNPs were dissolved in $2 \%$ DMSO [53,54]. Seventy-two Sprague-Dawley rats were divided into nine groups (eight rats/group) as illustrated in (Figure 7): Control group (C): rats were treated with $0.5 \mathrm{~mL}$ DMSO (2\%) for 14 days (at 9th and 10th weeks), DBT group: animals were treated (ip) with DBT $(4.5 \mathrm{mg} / \mathrm{kg}$ BW/day for two weeks (at 9th and 10th weeks), CSNPs group: rats were treated (ip) with $3.0 \mathrm{mg}$ CSNPs $/ \mathrm{kg}$ BW/day for two weeks (at 9th and 10th weeks), DBT-CSNP group: rats were treated (ip) with DBT-CSNPs (3.0 mg/kg BW/day for two weeks (at 9th and 10th weeks), $\mathrm{CCl}_{4}$ group: rats were injected (ip) with $0.5 \mathrm{~mL}$ of $99.9 \% \mathrm{CCl}_{4} / \mathrm{kg} \mathrm{BW}$, with equal amounts of olive oil, day after day for six weeks [14]. $\mathrm{CCl}_{4}$-CSNPs, $\mathrm{CCl}_{4}$-DBT, $\mathrm{CCl}_{4}$-DBT-CSNPs groups: rats were injected with $\mathrm{CCl}_{4}$ for six weeks and were then treated with the same doses and periods of CSNPs, DBT, and DBT-CSNPs. $\mathrm{CCl}_{4}$ - cisplatin: rats were injected with $\mathrm{CCl}_{4}$ for six weeks, and then they were treated with $4 \mathrm{mg}$ of cisplatin $/ \mathrm{kg} \mathrm{BW/day,} \mathrm{ip,} \mathrm{for} \mathrm{five} \mathrm{consecutive} \mathrm{days} \mathrm{[55].} \mathrm{At} \mathrm{the}$ end of the experimental period, all animals were fasted overnight, anesthetized with carbon dioxide, and then sacrificed. Blood was collected from the caudal vena cava and kept for 
$15 \mathrm{~min}$ at room temperature, after which the blood was centrifuged at $3000 \mathrm{rpm}$ for $10 \mathrm{~min}$, and the serum was kept at $-20{ }^{\circ} \mathrm{C}$ until use. The livers were extracted directly where small portions were taken and stored in $10 \%$ formalin for the histopathological screening. The remaining livers were washed with cold saline solution $(0.9 \% \mathrm{NaCl})$, divided into two parts, and stored at $-80^{\circ} \mathrm{C}$. One of these parts was homogenized using a glass-Teflon Homogenizer in nine volumes of $0.1 \mathrm{M}$ sodium phosphate buffer ( $\mathrm{pH}$ 7.4) containing $0.9 \% \mathrm{NaCl}$, and the homogenate was centrifuged at $4000 \mathrm{rpm}$ at $4{ }^{\circ} \mathrm{C}$ for $15 \mathrm{~min}$. The supernatant was stored at $-80^{\circ} \mathrm{C}$ until used for evaluation of the markers of OS (MDA, GSH levels, and the activities of GPx, SOD, GST, and GR). The other part was used for the determination of the expression levels of caspase-8, Bcl-2, Bax, and DNAF.

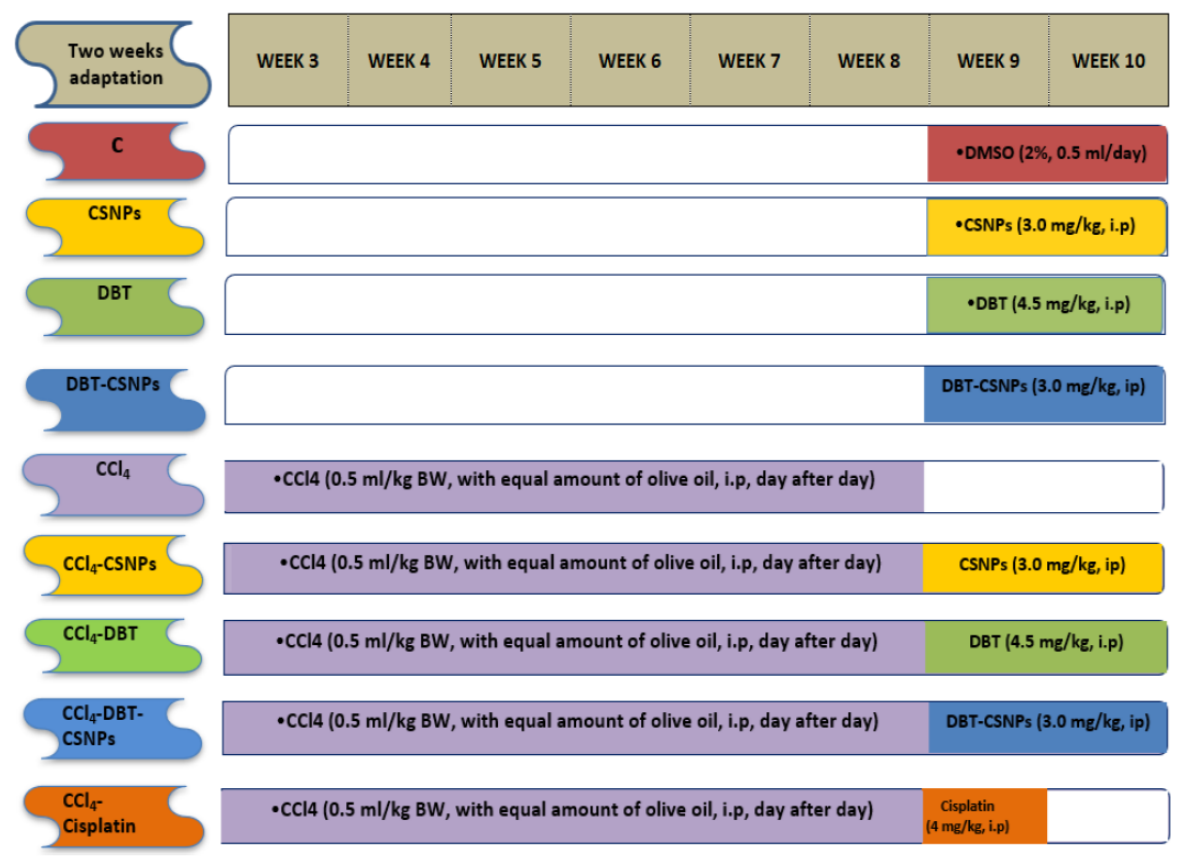

Figure 7. Illustration of the current experimental design.

\subsection{Effect of the Studied Compounds on OS Markers}

The level of MDA (as oxidant) and the antioxidants \{GSH level and the activities of GPx (EC 1.11.1.19), GR (EC 1.8.1.7), GST (EC 2.5.1.18), and SOD (EC 1.15.1.1)\} were determined according to the methods of Ohkawa, Ohishi [56] Ellman [57], Rotruck, Pope [58], Bergmeyer, Bergmeyer [59], Habig, Pabst [60], and Marklund and Marklund [61].

\subsection{Effect of the Studied Compounds on Apoptotic Markers}

\subsubsection{Determination of Gene Expressions of Bcl-2, Bax, and Caspase-8}

Total RNA was extracted from the liver tissues using an RNA isolation kit (Thermo Scientific, Fermentas, \#K0731, Waltham, MA, USA). Total RNA was measured by a NanoDrop 2000 spectrophotometer (Thermo Scientific, Waltham, MA, USA). A reverse transcription kit (Thermo Scientific, Fermentas, \#EP0451) was used to produce complementary DNA (cDNA). Then, the cDNA was magnified using 2X Maxima SYBR Green/ROX qPCR Master Mix (Thermo Scientific, USA, \# K0221). Table 3 shows the primers used for Bax, Bcl-2, caspase-8, and $\beta$-actin. The RT-PCR cycle parameters were $10 \mathrm{~min}$ at $95^{\circ} \mathrm{C}$ accompanied by 40 cycles, including denaturation at $95^{\circ} \mathrm{C}$ for $15 \mathrm{~s}$, annealing at $60^{\circ} \mathrm{C}$ for $30 \mathrm{~s}$, and elongation at $72{ }^{\circ} \mathrm{C}$ for $30 \mathrm{~s}$, with final elongation at $72{ }^{\circ} \mathrm{C}$ for $5 \mathrm{~min}$. A StepOnePlus ${ }^{\mathrm{TM}}$ RealTime PCR System (Applied Biosystems, Life technology (Carlsbad, CA, USA) was used for qRT-PCR. To prove the purity of the PCR products after each reaction, the division curve program was used. The critical threshold (CT) values of the target gene were normalized 
with quantities (CT) of a housekeeping gene ( $\beta$-actin) using the $2^{-\Delta \Delta C t}$ style to estimate the fold change in the target gene.

Table 3. Primers used in the synthesis of cDNA.

\begin{tabular}{ccc}
\hline Gene & $\begin{array}{c}\text { Forward Primer } \\
\left(\mathbf{5}^{\prime}-\mathbf{3}^{\prime}\right)\end{array}$ & $\begin{array}{c}\text { Reverse Primer } \\
\left(\mathbf{5}^{\prime}-\mathbf{3}^{\prime}\right)\end{array}$ \\
\hline Bcl-2 & ATCGCTCTGTGGATGACTGAGTAC & AGAGACAGCCAGGAGAAATCAAAC \\
Bax & ACACCTGAGCTGACCTTG & AGCCCATGATGGTTCTGATC \\
Caspase- 8 & CTGGGAAGGATCGACGATTA & CATGTCCTGCATTTTGATGG \\
$\boldsymbol{\beta}$-actin & AAGTCCCTCACCCTCCCAAAAG & AAGCAATGCTGTCACCTTCCC \\
\hline
\end{tabular}

\subsubsection{Determination of DNAF}

DNAF was determined using the agarose gel electrophoresis technique [51]. Liver tissues were homogenized in five volumes of $50 \mathrm{mM}$ Tris- $\mathrm{HCl}$ buffer containing $50 \mathrm{mM}$ EDTA and 20\% sucrose, pH 7.6. The genomic DNA was separated using a DNA purification kit (G-spin ${ }^{\mathrm{TM}}$ Total, Cat.No.17045, Korea). Then, $15 \mu \mathrm{g}$ of DNA/lane was loaded and separated by electrophoresis for $2 \mathrm{~h}$ on $1 \%$ agarose gel containing ethidium bromide $(10 \mu \mathrm{g} / \mathrm{mL})$. Finally, DNA bands were visualized using trans-illumination with ultraviolet light (Consort, Turnhout, Belgium).

\subsection{Effect of the Studied Compounds on Liver and Kidney Functions and the Lipid Profile}

Liver biomarkers involving serum AST (EC 2.6.1.1), ALT (EC 2.6.1.2), and ALP (EC 3.1.3.1) activities, STP and albumin, and LTP were assayed using commercial kits (Biosystem, Barcelona, Spain) [62-64]. The lipid profile (serum TG, cholesterol, HDL, and LDL levels) $[65,66]$ and kidney markers (urea and creatinine levels) were determined using kits (Biosystem, Barcelona, Spain) $[67,68]$.

\subsection{Liver Histopathological Analysis}

Liver histopathological examinations of the various studied groups were analyzed by fixing, processing, and embedding the liver tissues in paraffin wax. Sections of $5 \mu \mathrm{m}$ in thickness were broken and stained using hematoxylin and eosin $(\mathrm{H} \& \mathrm{E})$ for examination by a light microscope [69].

\subsection{Cell Cycle Analysis}

In the different cell cycle phases (G0/G1, S and G2/M), the distribution of HepG2 cells was estimated [70]. Briefly, HepG2 cells were divided into two parts: the first part was untreated, and the second part was treated with $40 \mu \mathrm{g} / \mathrm{mL}$ of DBT and DBT-CSNPs separately for $24 \mathrm{~h}$. All cells were then harvested and transferred to ice-cold ethanol (70\%) for $12 \mathrm{~h}$ at $4{ }^{\circ} \mathrm{C}$ and centrifuged for $5 \mathrm{~min}$ at $1000 \mathrm{rpm}$. Pellets were placed in propidium iodide $(0.05 \mathrm{mg} / \mathrm{mL})$ and RNase $(100 \mathrm{U} / \mathrm{mL})$ in phosphate buffer, $\mathrm{pH} 7.4$, incubated for $30 \mathrm{~min}$ at $37^{\circ} \mathrm{C}$, and DNA was determined by a flow cytometer (Attune ${ }^{\circledR}$ acoustic focusing flow cytometer, Thermo Scientific, Waltham, MA, USA). Then, cell cycle data were analyzed using Cellquest Software.

\subsection{Statistical Analysis}

Data were expressed as the means \pm SD (standard deviation). The comparisons between individuals were obtained using Duncan's multiple range test (DMRT) via oneway analysis of variance (ANOVA) by using SPSS, 18.0 Software, 2011 (SPSS Inc., Chicago, IL, USA). The values were estimated to be statistically significant when $p<0.05$.

\section{Conclusions}

The $\mathrm{LD}_{50}$ values of DBT and DBT-CSNPs are 1350 and $1800 \mathrm{mg} / \mathrm{kg}$, respectively. DBT and DBT-CSNPs have a therapeutic effect against $\mathrm{CCl}_{4}$-induced liver injuries via the reduction of apoptosis. DBT-CSNPs have a greater effect than DBT, and both compounds 
have a greater effect than cisplatin. Additionally, DBT and DBT-CSNPs have antineoplastic activities against the HepG2 cell line. Low doses of DBT and DBT-CSNPs for 14 days have no adverse effect in healthy rats. Therefore, further research must be done on DBT-CSNPs and DBT to identify their clinical implementations.

Author Contributions: N.Z.S. suggested this study, contributed to its design as well as organization, participated in the sequence arrangement, wrote and reviewed and approved manuscript, and agrees to be accountable for all aspects of the work, ensuring that questions related to the accuracy or integrity of any part of the work are appropriately investigated and resolved. S.A.Y. participated in the suggestion of this study, participated in its design, carried out the experimental part in vitro and in vivo, performed the statistical analysis and drew the figures, and was a major contributor in writing and reviewing the manuscript. D.A. participated in the statistical analysis. S.Y.S. participated in the supervision of the preparation of the studied complexes and read and approved the final manuscript. S.R.S. participated in the suggestion of this study and its design, supervised the experimental part and the statistical analysis, and contributed to writing and reviewing the manuscript. All authors have read and agreed to the published version of the manuscript.

Funding: The authors declare that there was no funding for this research.

Institutional Review Board Statement: All animal procedures were carried out in accordance with the Ethics Committee of the Faculty of Science, Alexandria University. We obtained institutional review board approval from Alexandria University for the research described (Approval No. AU 04 2006202 02, approved on 20/06/2020).

Informed Consent Statement: Not applicable.

Data Availability Statement: All data generated or analyzed during this study are included in this published article.

Acknowledgments: The authors thank Kamel R. Shoueir (Institute of Nanoscience \& Nanotechnology, Kafrelsheikh University, Egypt) for participation in the preparation of the studied complexes in the form of nanoparticles. Further, the authors express their gratitude to Ahmed Alaa Abdul-Aziz, Department of Endocrinology, Faculty of Medicine, Alexandria University, for his participation in the histological examination of the liver.

Conflicts of Interest: All authors have no conflict of interest.

\begin{tabular}{|c|c|}
\hline Apaf-1 & apoptosis protease activating factor- 1 \\
\hline $\mathrm{CCl}_{4}$ & carbon tetrachloride \\
\hline$\cdot \mathrm{CCl}_{3}$ & trichloromethyl radical \\
\hline $\mathrm{CCl}_{3} \mathrm{OO}^{\bullet}$ & trichloromethylperoxy radicals \\
\hline CS & chitosan \\
\hline CSNPs & chitosan nanoparticles \\
\hline DBT & titanium (IV)-thiophenolate complex \\
\hline DBT-CSNPS & titanium (IV)-dithiophenolate -Chitosan nanocomposite \\
\hline DMSO & Dimethyl sulfoxide \\
\hline DTP & dithiophenolato ligand \\
\hline GPx & total glutathione peroxidase \\
\hline GR & glutathione reductase \\
\hline GSH & reduced glutathione \\
\hline GST & glutathione-S-transferase \\
\hline GSSG & oxidized glutathione \\
\hline HepG2 & human liver cancer \\
\hline MDA & malondialdehyde \\
\hline RNS & reactive nitrogen species \\
\hline ROS & reactive oxygen speci \\
\hline SOD & superoxide dismutase \\
\hline THLE2 & normal liver cell \\
\hline
\end{tabular}




\section{References}

1. Al-Seeni, M.N.; El Rabey, H.A.; Zamzami, M.A.; Alnefayee, A.M. The hepatoprotective activity of olive oil and Nigella sativa oil against $\mathrm{CCl}_{4}$ induced hepatotoxicity in male rats. BMC Complement. Altern. Med. 2016, 16, 438. [CrossRef]

2. Shaban, N.Z.; El-Kersh, M.A.R.; Bader-Eldin, M.M.; Kato, S.A.; Hamoda, A.F. Effect of Punica granatum (Pomegranate) juice extract on healthy liver and hepatotoxicity induced by diethylnitrosamine and phenobarbital in male rats. J. Med. Food 2014, 17, 339-349. [CrossRef] [PubMed]

3. Abdel-Monem, N.M.; El-Saadani, M.A.; Daba, A.S.; Saleh, S.R.; Aleem, E. Exopolysaccharide-peptide complex from oyster mushroom (Pleurotus ostreatus) protects against hepatotoxicity in rats. Biochem. Biophys. Rep. 2020, 24, 100852. [CrossRef] [PubMed]

4. Liu, Y.; Wen, P.-H.; Zhang, X.-X.; Dai, Y.; He, Q. Breviscapine ameliorates $\mathrm{CCl}_{4}$-induced liver injury in mice through inhibiting inflammatory apoptotic response and ROS generation. Int. J. Mol. Med. 2018, 42, 755-768. [CrossRef] [PubMed]

5. Wang, Y.; Tang, C.; Zhang, H. Hepatoprotective effects of kaempferol 3-O-rutinoside and kaempferol 3-O-glucoside from Carthamus tinctorius L. on $\mathrm{CCl}_{4}$-induced oxidative liver injury in mice. J. Food Drug Anal. 2015, 23, 310-317. [CrossRef]

6. Dutta, S.; Chakraborty, A.K.; Dey, P.; Kar, P.; Guha, P.; Sen, S.; Kumar, A.; Sen, A.; Chaudhuri, T.K. Amelioration of CCl 4 induced liver injury in swiss albino mice by antioxidant rich leaf extract of Croton bonplandianus Baill. PLoS ONE 2018, 13, e0196411. [CrossRef]

7. Das, R.; Vupputuri, S.; Hu, Q.; Chen, Y.; Colorado, H.; Guo, Z.; Wang, Z. Synthesis and characterization of antiflammable vinyl ester resin nanocomposites with surface functionalized nanotitania. ES Mater. Manuf. 2020, 8, 46-53. [CrossRef]

8. El-Sayed, A.; Kamel, M. Advances in nanomedical applications: Diagnostic, therapeutic, immunization, and vaccine production Environ. Sci. Pollut. Res. 2020, 27, 19200-19213. [CrossRef] [PubMed]

9. Shaban, N.Z.; Aboelsaad, A.M.; Shoueir, K.R.; Abdulmalek, S.A.; Awad, D.; Shaban, S.Y.; Mansour, H. Chitosan-based dithiophenolato nanoparticles: Preparation, mechanistic information of DNA binding, antibacterial and cytotoxic activities. J. Mol. Liq. 2020, 318, 114252. [CrossRef]

10. Li, J.; Cai, C.; Sun, T.; Wang, L.; Wu, H.; Yu, G. Chitosan-based nanomaterials for drug delivery. Molecules 2018, $23,2661$. [CrossRef] [PubMed]

11. Hafez, H.S.; Ghareeb, D.A.; Saleh, S.R.; Abady, M.M.; El Demellawy, M.A.; Hussien, H.; Abdel-Monem, N. Neuroprotective effect of ipriflavone against scopolamine-induced memory impairment in rats. Psychopharmacology 2017, 234, 3037-3053. [CrossRef]

12. Marcellin, P.; Kutala, B.K. Liver diseases: A major, neglected global public health problem requiring urgent actions and large-scale screening. Liver Int. Off. J. Int. Assoc. Study Liver 2018, 38, 2-6. [CrossRef] [PubMed]

13. Rashed, W.M.; Kandeil, M.A.M.; Mahmoud, M.O.; Ezzat, S. Hepatocellular Carcinoma (HCC) in Egypt: A comprehensive overview. J. Egypt. Natl. Cancer Inst. 2020, 32, 5. [CrossRef]

14. Karaca, O.; Paksoy, S.; Hismiogullsri, S.; Kus, M.; Sunay, F.; Gulcen, B.; Ozcan, E.J.A.M.M. Prevention of carbontetrachlorideinduced liver injury in rats by omega-3-fatty acids. Acta Med. Mediterr. 2017, 33, 137-144.

15. Ananth, H.; Kundapur, V.; Mohammed, H.S.; Anand, M.; Amarnath, G.S.; Mankar, S. A review on biomaterials in dental implantology. Int. J. Biomed. Sci. IJBS 2015, 11, 113-120.

16. Shaban, N.Z.; Aboelsaad, A.M.; Awad, D.; Abdulmalek, S.A.; Shaban, S.Y. Therapeutic effect of dithiophenolato chitosan nanocomposites against carbon tetrachloride-induced hepatotoxicity in rats. Environ. Sci. Pollut. Res. 2021, 8, 1-16. [CrossRef]

17. Shaban, N.Z.; Yehia, S.A.; Shoueir, K.R.; Saleh, S.R.; Awad, D.; Shaban, S.Y. Design, DNA binding and kinetic studies, antibacterial and cytotoxic activities of stable dithiophenolato titanium (IV)-chitosan Nanocomposite. J. Mol. Liq. 2019, 287, 111002. [CrossRef]

18. Shaban, S.Y.; Ramadan, A.E.-M.M.; Heinemann, F.W. Titanium isopropoxide complexes containing diamine bis-thiolato based [N2S2]2- ligands; effect of steric bulk on coordination features. Inorg. Chem. Commun. 2012, 20, 135-137. [CrossRef]

19. Wang, J.; Zhou, G.; Tiancheng, W.; Yu, H.; Wang, T.; Ma, Y.; Jia, G.; Gao, Y.; Li, Y.-F.; Sun, J. Acute toxicity and biodistribution of different sized titanium dioxide particles in mice after oral administration. Toxicol. Lett. 2007, 168, 176-185. [CrossRef] [PubMed]

20. Alkreathy, H.M.; Khan, R.A.; Khan, M.R.; Sahreen, S. CCl4 induced genotoxicity and DNA oxidative damages in rats: Hepatoprotective effect of Sonchus arvensis. BMC Complement. Altern. Med. 2014, 14, 452. [CrossRef] [PubMed]

21. Kurutas, E.B. The importance of antioxidants which play the role in cellular response against oxidative/nitrosative stress: Current state. Nutr. J. 2015, 15, 1-22. [CrossRef] [PubMed]

22. Shah, M.D.; A Dsouza, U.J.; Iqbal, M. The potential protective effect of Commelina nudiflora L. against carbon tetrachloride (CCl4)-induced hepatotoxicity in rats, mediated by suppression of oxidative stress and inflammation. Environ. Heal. Prev. Med. 2017, 22, 1-19. [CrossRef]

23. Ighodaro, O.; Akinloye, O. First line defence antioxidants-superoxide dismutase (SOD), catalase (CAT) and glutathione peroxidase (GPX): Their fundamental role in the entire antioxidant defence grid. Alex. J. Med. 2018, 54, 287-293. [CrossRef]

24. Kale, J.; Osterlund, E.J.; Andrews, D.W. BCl-2 family proteins: Changing partners in the dance towards death. Cell Death Differ. 2018, 25, 65-80. [CrossRef]

25. Hassan, M.; Watari, H.; AbuAlmaaty, A.; Ohba, Y.; Sakuragi, N. Apoptosis and molecular targeting therapy in cancer. Biomed. Res. Int. 2014, 2014, 150845. [CrossRef] [PubMed]

26. Campbell, K.J.; Tait, S.W.G. Targeting BCl-2 regulated apoptosis in cancer. Open Biol. 2018, 8, 180002. [CrossRef]

27. Pistritto, G.; Trisciuoglio, D.; Ceci, C.; Garufi, A.; D'Orazi, G. Apoptosis as anticancer mechanism: Function and dysfunction of its modulators and targeted therapeutic strategies. Aging 2016, 8, 603-619. [CrossRef] 
28. Kalkavan, H.; Green, D.R. MOMP, cell suicide as a BCl-2 family business. Cell Death Differ. 2018, 25, 46-55. [CrossRef]

29. Liu, Z.; Ding, Y.; Ye, N.; Wild, C.; Chen, H.; Zhou, J. Direct Activation of Bax Protein for Cancer Therapy. Med. Res. Rev. 2016, 36, 313-341. [CrossRef]

30. Eltahir, H.M.; Nazmy, M.H. Esomeprazole ameliorates $\mathrm{CCl}_{4}$ induced liver fibrosis in rats via modulating oxidative stress, inflammatory, fibrogenic and apoptotic markers. Biomed. Pharmacother. 2018, 97, 1356-1365. [CrossRef]

31. Yokoyama, C.; Sueyoshi, Y.; Ema, M.; Mori, Y.; Takaishi, K.; Hisatomi, H. Induction of oxidative stress by anticancer drugs in the presence and absence of cells. Oncol. Lett. 2017, 14, 6066-6070. [CrossRef]

32. Fong, C. Free Radical Anticancer Drugs and Oxidative Stress: ORAC and CellROX-Colorectal Cancer Cells by Quantum Chemical Determinations. Ph.D. Thesis, Eigenenergy, Adelaide, Australia, 2018.

33. Roos, W.P.; Kaina, B. DNA damage-induced cell death: From specific DNA lesions to the DNA damage response and apoptosis. Cancer Lett. 2013, 332, 237-248. [CrossRef] [PubMed]

34. Guo, X.L.; Liang, B.; Wang, X.W.; Fan, F.G.; Jin, J.; Lan, R.; Yang, J.H.; Wang, X.C.; Jin, L.; Cao, Q. Glycyrrhizic acid attenuates $\mathrm{CCl}_{4}$-induced hepatocyte apoptosis in rats via a p53-mediated pathway. World J. Gastroenterol. 2013, 19, 3781-3791. [CrossRef] [PubMed]

35. Jia, X.; Wang, S.; Zhou, L.; Sun, L. The potential liver, brain, and embryo toxicity of titanium dioxide nanoparticles on mice. Nanoscale Res. Lett. 2017, 12, 478. [CrossRef]

36. Pujalté, I.; Passagne, I.; Brouillaud, B.; Tréguer, M.; Durand, E.; Ohayon-Courtès, C.; l'Azou, B. Cytotoxicity and oxidative stress induced by different metallic nanoparticles on human kidney cells. Part. Fibre Toxicol. 2011, 8, 10. [CrossRef] [PubMed]

37. El-Said, K.S.; Ali, E.M.; Kanehira, K.; Taniguchi, A. Molecular mechanism of DNA damage induced by titanium dioxide nanoparticles in toll-like receptor 3 or 4 expressing human hepatocarcinoma cell lines. J. Nanobiotechnol. 2014, 12, 48. [CrossRef]

38. Liu, S.; Xu, L.; Zhang, T.; Ren, G.; Yang, Z. Oxidative stress and apoptosis induced by nanosized titanium dioxide in PC12 cells. Toxicology 2010, 267, 172-177. [CrossRef]

39. Faedmaleki, F.; Shirazi, F.; Ejtemaeimehr, S.; Anjarani, S.; Salarian, A.A.; Ashtiani, H.; Rastegar, H. Study of silymarin and Vitamin E protective effects on silver nanoparticle toxicity on mice liver primary cell culture. Acta Med. Iran. 2016, 54, 85-95.

40. Jiang, Y.; Yu, X.; Su, C.; Zhao, L.; Shi, Y. Chitosan nanoparticles induced the antitumor effect in hepatocellular carcinoma cells by regulating ROS-mediated mitochondrial damage and endoplasmic reticulum stress. Artif. Cells Nanomed. Biotechnol. 2019, 47, 747-756. [CrossRef]

41. Miethling-Graff, R.; Rumpker, R.; Richter, M.; Verano-Braga, T.; Kjeldsen, F.; Brewer, J.; Hoyland, J.; Rubahn, H.-G.; Er, H. Exposure to silver nanoparticles induces size- and dose-dependent oxidative stress and cytotoxicity in human colon carcinoma cells. Toxicol. Vitr. 2014, 28, 1280-1289. [CrossRef]

42. Pratibha, R.; Sameer, R.; Rataboli, P.V.; Bhiwgade, D.A.; Dhume, C.Y. Enzymatic studies of cisplatin induced oxidative stress in hepatic tissue of rats. Eur. J. Pharmacol. 2006, 532, 290-293. [CrossRef]

43. Abouzeinab, N. Cytoprotective effect and antioxidant properties of silymarin on cisplatin induced hepatotoxicity in rats: A biochemical and histochemical study. Int. J. Cancer Res. 2013, 9, 9-23. [CrossRef]

44. Katarina, R.; Isidora, S.; Vladimir, Z.; Ivan, S.; Nevena, J.; Vladimir, J.; Dragan, D.; Slobodan, N. The Platinum (II) complexes induced oxidative stress of isolated rat heart. Serb. J. Exp. Clin. Res. 2017, 18, 111-117.

45. Silici, S.; Ekmekcioglu, O.; Kanbur, M.; Deniz, K. The protective effect of royal jelly against cisplatin-induced renal oxidative stress in rats. World J. Urol. 2011, 29, 127-132. [CrossRef]

46. Ateyya, H.; Yosef, H.; Nader, M.A. Ameliorative effect of trimetazidine on cisplatin-induced hepatotoxicity in rats. Can. J. Physiol. Pharmacol. 2016, 94, 225-230. [CrossRef] [PubMed]

47. Hong, S.H.; Cha, H.-J.; Hwang-Bo, H.; Kim, M.Y.; Kim, S.Y.; Ji, S.Y.; Cheong, J.; Park, C.; Lee, H.; Kim, G.-Y.; et al. Anti-proliferative and pro-apoptotic effects of Licochalcone A through ROS-mediated cell cycle arrest and apoptosis in human bladder cancer cells. Int. J. Mol. Sci. 2019, 20, 3820. [CrossRef] [PubMed]

48. Shaban, N.Z.; El-Kersh, M.A.L.; El-Rashidy, F.H.; Habashy, N.H. Protective role of Punica granatum (pomegranate) peel and seed oil extracts on diethylnitrosamine and phenobarbital-induced hepatic injury in male rats. Food Chem. 2013, 141, 1587-1596. [CrossRef] [PubMed]

49. Bhattacharya, T.; Maishu, S.P.; Akter, R.; Rahman, M.H.; Akhtar, M.F.; Saleem, A.; Bin-Jumah, M.; Kamel, M.; Abdel-Latif, M.A.; Abdel-Daim, M.M. A review on natural sources derived protein nanoparticles as anticancer agents. Curr. Top. Med. Chem. 2021, 21, 1014-1026. [CrossRef]

50. Weinstein, J.N. Cell lines battle cancer. Nature 2012, 483, 544-545. [CrossRef]

51. Mirabelli, P.; Coppola, L.; Salvatore, M. Cancer cell lines are useful model systems for medical research. Cancers 2019, 11, 1098. [CrossRef]

52. Kärber, G. Beitrag zur kollektiven Behandlung pharmakologischer Reihenversuche. Naunyn-Schmiedebergs Arch. für Exp. Pathol. und Pharmakol. 1931, 162, 480-483. [CrossRef]

53. Baravalia, Y.; Vaghasiya, Y.; Chanda, S. Brine shrimp cytotoxicity, anti-inflammatory and analgesic properties of woodfordia fruticosa Kurz flowers. Iran. J. Pharm. Res. IJPR 2012, 11, 851-861.

54. Galvao, J.; Davis, B.; Tilley, M.; Normando, E.; Duchen, M.R.; Cordeiro, M.F. Unexpected low-dose toxicity of the universal solvent DMSO. FASEB J. Off. Publ. Fed. Am. Soc. Exp. Biol. 2014, 28, 1317-1330. [CrossRef] 
55. Wang, Y.; Huang, F.; Cai, H.; Wu, Y.; He, G.; Tan, W.-S. The efficacy of combination therapy using adeno-associated virus-TRAIL targeting to telomerase activity and cisplatin in a mice model of hepatocellular carcinoma. J. Cancer Res. Clin. Oncol. 2010, 136, 1827-1837. [CrossRef]

56. Ohkawa, H.; Ohishi, N.; Yagi, K. Assay for lipid peroxides in animal tissues by thiobarbituric acid reaction. Anal. Biochem. 1979, 95, 351-358. [CrossRef]

57. Ellman, G.L. Tissue sulfhydryl groups. Arch. Biochem. Biophys. 1959, 82, 70-77. [CrossRef]

58. Rotruck, J.T.; Pope, A.L.; Ganther, H.E.; Swanson, A.; Hafeman, D.G.; Hoekstra, W. Selenium: Biochemical role as a component of glutathione peroxidase. Science 1973, 179, 588-590. [CrossRef]

59. Bergmeyer, H.; Bergmeyer, J.; Grassl, M. Methods of Enzymatic Analysis, 3rd ed; Verlag Chemie: Weinheim, Germany, 1983; Volume VI.

60. Habig, W.H.; Pabst, M.J.; Jakoby, W.B. Glutathione S-transferases. The first enzymatic step in mercapturic acid formation. J. Biol. Chem. 1974, 249, 7130-7139. [CrossRef]

61. Marklund, S.; Marklund, G. Involvement of the superoxide anion radical in the autoxidation of pyrogallol and a convenient assay for superoxide dismutase. Eur. J. Biochem. 1974, 47, 469-474. [CrossRef]

62. Reitman, S.; Frankel, S. A colorimetric method for the determination of serum glutamic oxalacetic and glutamic pyruvic transaminases. Am. J. Clin. Pathol. 1957, 28, 56-63. [CrossRef]

63. Doumas, B.T.; Ard Watson, W.; Biggs, H.G. Albumin standards and the measurement of serum albumin with bromcresol green. Clin. Chim. Ccta. Int. J. Clin. Chem. 1971, 31, 87-96. [CrossRef]

64. Gornall, A.G.; Bardawill, C.J.; David, M.M. Determination of serum proteins by means of the biuret reaction. J. Biol. Chem. 1949, 177, 751-766. [CrossRef]

65. Burstein, M.; Scholnick, H.; Morfin, R. Rapid method for the isolation of lipoproteins from human serum by precipitation with polyanions. J. Lipid Res. 1970, 11, 583-595. [CrossRef]

66. Fossati, P.; Prencipe, L. Serum triglycerides determined colorimetrically with an enzyme that produces hydrogen peroxide. Clin. Chem. 1982, 28, 2077-2080. [CrossRef]

67. Henry, R.J.; Winkelman, J.W.; Cannon, D.C. Clinical Chemistry; Principles and Technics; Medical Dept., Harper \& Row: Hagerstown, MD, USA, 1974; p. 1629.

68. Patton, C.J.; Crouch, S. Spectrophotometric and kinetics investigation of the Berthelot reaction for the determination of ammonia. Anal. Chem. 1977, 49, 464-469. [CrossRef]

69. Suzuki, H.; Suzuki, K. Rat hypoplastic kidney (hpk/hpk) induces renal anemia, hyperparathyroidism, and osteodystrophy at the end stage of renal failure. J. Vet. Med. Sci. 1998, 60, 1051-1058. [CrossRef]

70. Shanmugasundaram, T.; Radhakrishnan, M.; Gopikrishnan, V.; Kadirvelu, K.; Balagurunathan, R. Biocompatible silver, gold and silver/gold alloy nanoparticles for enhanced cancer therapy: In vitro and in vivo perspectives. Nanoscale 2017, 9, 16773-16790. [CrossRef] 